\title{
Subsidiary power, cultural intelligence and interpersonal knowledge transfer between subsidiaries within the multinational enterprise
}

\begin{abstract}
We propose that individual-level knowledge transfer between subsidiaries within a multinational enterprise depends on the perceived relative power of the subsidiary and the cultural intelligence of individuals. Using a sample of 333 research and development (R\&D) subsidiary employees of foreign Multinational Enterprises (MNEs) in India, we find that the perceived subsidiary power has a direct positive significant effect on knowledge sharing, and an indirect significant effect, through organizational identification, on knowledge seeking. Further, cultural intelligence moderates the effect of organizational identification on knowledge seeking, and the indirect effect of the perceived subsidiary power on it. The findings highlight the role of organizational identification and cultural intelligence in explaining the impact of the perceived subsidiary power on interpersonal knowledge transfer within the MNE.
\end{abstract}

Keywords: Knowledge transfer, Subsidiary power, Cultural intelligence, India

NOTE: This is the final submitted copy of the paper accepted by the journal. Pease cite this article as:

Phookan, H., \& Sharma, R. R. (2021). Subsidiary power, cultural intelligence and interpersonal knowledge transfer between subsidiaries within the multinational enterprise. Journal of International Management, https://doi.org/10.1016/j.intman.2021.100859

Final published article is available the journal website: https://doi.org/10.1016/j.intman.2021.100859 


\section{Introduction}

The performance and success of a multinational enterprise (MNE) depends upon the integration and transfer of its knowledge across its geographically dispersed subsidiaries (Argote \& Ingram, 2000; Caimo \& Lomi, 2015). Kogut and Zander (1993) attributed MNEs' ability to transfer their idiosyncratic knowledge across national borders to the internalization and creation of MNEs. Moreover, knowledge transfer leads to better coordination and innovation (Kotabe, Dunlap-Hinkler, Parente, \& Mishra, 2007; Phene \& Almeida, 2008).

Intra-MNE knowledge transfer may happen at organizational and individual levels. However, most studies have examined knowledge transfer within the MNE at the unit/organizational level rather than at the individual level of analysis, which remains largely unexplored (Dasí, Pedersen, Gooderham, Elter, \& Hildrum, 2017; Foss \& Pedersen, 2019; Foss, Husted, \& Michailova, 2010). As aptly put by Makela, Kalla, and Piekkari (2007), "The issue of who interacts with whom is of fundamental importance to how knowledge flows internally but has thus far received surprisingly little attention in the literature concerning multinational corporations" (p.2).

Moreover, the knowledge-based view proposes that individuals are the locus of knowledge in the organization as knowledge creation, storage and efficient transfer depends upon individual specialization (Grant, 1996). Interpersonal knowledge transfer relationships are conduits of knowledge and information flow in the organization (Nebus, 2006). Due to the exchange of opinions and insights between individuals, they are not only the channels of knowledge flows, but also the "prisms" that shape perception (Podolny, 2001). They act as boundary spanners integrating activities across multiple cultural, organizational and institutional contexts (Schotter, Mudambi, Doz, \& Gaur, 2017). Individual-level linkages are critical as they form an important component of global innovation networks (Cano-Kollmann, Hannigan, \& Mudambi, 2018). They are integral to achieving lateral collaboration across MNE units. However, individuals, as agents of interpersonal knowledge transfer are heterogeneous (Felin \& Hesterly, 2007). Therefore, knowledge transfer behaviour is also less likely to be homogeneous across different employees. It is independent to each individual and may not always align with the goals of the organization (Bjerregaard \& Klitmoller, 2016). Thus, there is a need to study individual-level knowledge transfer behaviour between subsidiaries within the MNE.

Subsidiaries in an MNE are separated by internal boundaries. They are semiautonomous and have different roles to play. Based on their roles, responsibilities, and 
idiosyncratic characteristics, a subsidiary can gain more bargaining power within the MNE and exert considerable influence on MNE decisions (Ciabuschi, Dellestrand, \& Kappen, 2012; Mudambi \& Navarra, 2004). Therefore, power is important to a subsidiary as it can have great influence over various MNE processes which impact the subsidiary's development as well as its survival in the MNE (Balogun, Jarzabkowski, \& Vaara, 2011). Because subsidiary power is important for a subsidiary and dynamics of power cause power to ebb and flow within the MNE, it is likely to influence each individual employee's knowledge transfer behaviour across different units. Although subsidiary power has been well studied at the organizational level but its impact on interpersonal-level knowledge transfer is yet to be examined (Ciabuschi et al., 2012; Frenkel, 2008; Whittle, Mueller, Gilchrist, \& Lenney, 2016). That is the focus of this study.

As the focus of this paper is on individual-level knowledge transfer, our main research question is: does MNE employees' perception of their subsidiary's relative power (here after, perceived subsidiary power) influence their knowledge transfer engagement with other subsidiaries within the MNE. We have addressed this research question by examining: 1) the direct and indirect effect of perceived subsidiary power on knowledge transfer through organizational identification, and 2) the moderating effects of cultural intelligence on the indirect effects of perceived subsidiary power on knowledge transfer.

The mediating role of organizational identification is based on insights from social identity theory (Tajfel, 1978; Turner, 1975). On the other hand, cultural intelligence is argued as a moderator because the involvement of individual actors makes individual cognitive skills important for interpersonal interactions. An employee's skills and capabilities to interact crossculturally are likely to play a crucial role in inter-subsidiary knowledge transfer behaviour. This is because such a behaviour is likely to involve cross-cultural interactions as subsidiaries are generally located in different countries. The role of cultural intelligence in achieving success while dealing with counterparts from different countries and cultures has been established in the literature (Sharma, 2019). It is also found to play an important role in cross-cultural interactions and knowledge transfers in MNEs (Vlajčić, Caputo, Marzi, \& Dabić, 2019). Recent literature also calls to examining the moderating role of cultural intelligence in various settings (Ott \& Michailova, 2018; Rockstuhl \& Van Dyne, 2018)

We posed our research questions in the research and development (R\&D) units of foreign MNEs in India. India is fast emerging as a major destination for high-end R\&D projects (Gupta \& Gupta, 2014) and major organizations have their R\&D centres in India (CanoKollmann et al., 2018). Due to the presence of knowledge clusters, India has become an integral 
part of the global knowledge network. The 333 individual responses collected from employees working in $40 \mathrm{R} \& \mathrm{D}$ subsidiaries of different foreign MNEs in India are analysed using Confirmatory Factor Analysis (Byrne, 2010) and Conditional Process Analysis (Hayes, 2018).

Our study makes three key contributions. Firstly, by examining the impact of perceived subsidiary power we enhance understanding of how certain organizational factors can be utilised to influence inter-personal, intra-MNE knowledge transfers. This is achieved by integrating insights from the knowledge-based view and social identity theory. By doing so, we are also incorporating an 'identity-based quasi-formal' mechanism (e.g. subsidiary power) to the knowledge governance approach (Foss, 2007) which includes formal and informal knowledge governance mechanisms. Secondly, in the light of recent calls to examine the moderating effects of cultural intelligence (Ott \& Michailova, 2018; Rockstuhl \& Van Dyne, 2018), we contribute by establishing the moderating effects of cultural intelligence on the indirect effect of perceived subsidiary power through organizational identification on such knowledge transfers. It highlights how personal/social/cognitive factors (e.g. cultural intelligence) interact with organizational structures and processes (subsidiary power) to influence knowledge transfer with the multinational enterprise. Finally, having India as the context of the study helps to gain useful insights on the knowledge transfer behaviour of R\&D employees from India, a large emerging economy of interest to many MNEs.

The paper is structured as follows. Section 2 provides an overview of relevant literature and builds hypotheses. Section 3 describes the research methods and data. The data analysis and results are presented in Section 4. The final section discusses the study findings, presents theoretical and managerial implications, limitations and future research questions.

\section{Literature and hypotheses}

\subsection{Overview of the literature}

The impact of organizational factors on organizational-level knowledge transfer is well examined. Various organizational-level antecedents that impact organizational level knowledge transfer within an MNE can be summarised as characteristics of the actors, relational factors, formal mechanisms, homophily and contextual perceptions. The ability and willingness of the headquarters or the subsidiary to send or receive knowledge are two important characteristics (Minbaeva, 2007; Noorderhaven \& Harzing, 2009; Tseng, 2015). The higher the ability and motivation of the employees in an organization to recognise, assimilate and apply external knowledge, more knowledge will be transferred to the organization (Cohen \& Levinthal, 1990). A receiver's absorptive capacity, which involves two elements - prior 
knowledge and intensity of effort, is a major determinant of the effectiveness and efficiency of the knowledge transfer process (Gupta \& Govindarajan, 2000; Minbaeva, 2007; Szulanski, 1996).

A close relationship between the sender and receiver units due to frequent communication (Crespo, Griffith, \& Lages, 2014), previous cooperation (Ciabuschi et al., 2012), integrated work processes (Noorderhaven \& Harzing, 2009), and interdependent work flows (Bartlett \& Ghoshal, 1989) eases the process of international knowledge transfer by reducing motivational and cognitive problems (Szulanski, 1996). Other relational factors such as identification with the source (HQ) or competition with peer subunits also impact knowledge transfer and implementation in the subsidiaries (Hansen, Mors \& Lovas, 2005; Kostova \& Roth, 2002; Tsai, 2002).

Organizations use formal mechanisms such as giving more autonomy to the subsidiary (Ciabuschi, Martín \& Ståhl, 2010), setting subsidiary performance evaluation criteria (Björkman, Barner-Rasmussen \& Li, 2004) or HRM practices (Minbaeva, Pedersen, Björkman, Fey, \& Park., 2003), with an aim to facilitate knowledge transfers between the units. Organizational contextual or cultural or language similarity (i.e. homophily) increases interaction between the parties resulting in more knowledge transfer (Ambos \& Ambos, 2009; Reiche, Harzing \& Pudelko, 2015; Schlegelmilch \& Chini, 2003) between units.

Contextual perceptions and knowledge transfers between subsidiaries imply competitive tension and the existence of a relationship of power and politics between the units (HQ-subsidiary/subsidiary-subsidiary). Knowledge transfer between the HQ and the subsidiary is affected by power and political relationships. Because of the HQ's power over the subsidiary, subsidiary managers may hide or not share important information or knowledge of the local market with the HQ which affects the flow of subsidiary knowledge to the HQ (Wong, Ho, \& Lee, 2008; Whittle et al., 2016).

In terms of the impact of organizational factors on interpersonal knowledge transfer within the MNE, such organizational-level antecedents can be classified as formal or informal mechanisms (Foss, Minbaeva, Pedersen, \& Reinholt, 2009; Foss et al., 2010). Formal mechanisms include human resource management practices such as job design, rewards and incentives, training and development, which impact individual's ability and motivation to share knowledge (Minbaeva, 2013; Morris, Zhong, \& Makhija, 2015). On the other hand, the informal aspects relate to trust, networks, social ties, organizational values and culture, identity and identification (Argote \& Kane, 2009; Michailova \& Husted, 2003, Michailova \& Minbaeva, 2012), which impact individual-level knowledge transfer by influencing 
individuals' cognitive and behavioural levels. Apart from the formal and informal governance mechanisms, there are certain other organizational-level characteristics (e.g. subsidiary power, status, intra-MNE competition), which may influence individual knowledge sharing behaviour through cognitive framing or framing of individual perceptions. These factors are likely to influence knowledge transfer through individual's extent of identity with the subsidiary (Turner, 1975).

We use social identity theory (Tajfel, 1978; Turner, 1975) as the underlying theory that explains how subsidiary power influences individual knowledge transfers within the MNE. Social identity theory posits that people tend to categorise themselves and others into social groups based on certain group prototypical characteristics (Turner, 1975). Organizational identification (OI) or identification with an organization, which is also a social group, is also a form of social identification. "OI is defined as the degree to which a member defines himself/herself by the same attributes he/she believes define the organization" (Dutton, Dukerich, \& Harquail, 1994, p. 1). Employees in an organization are affected by separate group identification, based on their distinction between themselves and others (Gregersen \& Black, 1992). Dual organizational identification of subsidiary employees, where the employees have various degrees of identification with both the MNE and the local subsidiary unit, is also common (Reade, 2001; Smale, Björkman, Ehrnrooth, John, Mäkelä, \& Sumelius, 2015; Vora \& Kostova, 2007). However, it is found that identification with the more proximate work group, such as the subsidiary, is more important in determining organizational attitude and behaviour (Bartels, Pruyn, De Jong, \& Joustra, 2007; Smale et al., 2015).

\subsection{The direct effect of subsidiary power on interpersonal knowledge transfer}

Subsidiary power refers to a subsidiary's ability to influence its parent's decision in strategic and operational activities (Dörrenbächer \& Gammelgaard, 2006) and having the freedom (autonomy) to pursue its own goals (Ambos, Andersson, \& Birkinshaw, 2010; Najafi-Tavani, Zaefarian, Naudé, \& Giroud, 2015). Subsidiaries differ in terms of their mandates, responsibilities and functions (Birkinshaw \& Hood, 1998). They are semi-autonomous units with independent objectives (Ambos et al., 2010). Key sources with which subsidiaries gain power over other subsidiaries include systemic power, micro-political bargaining power and resource dependency relationships (Dörrenbächer \& Gammelgaard, 2011). Systemic power is gained when a subsidiary is responsible for a specific function which is critical to the proper functioning of the value-chain network in the MNE. Micro-political bargaining power is derived from a subsidiary exerting influence on the HQ through strategic information politics 
or other forms of manipulative behaviour. Finally, power from resource dependency is derived from a subsidiary's control over critical resources that are valuable to the MNE.

Knowledge is an important source of subsidiary power (Mudambi \& Navarra, 2004). Possession of power may create a perception of possessing valuable and superior knowledge. Individual members of a high-power unit of an MNE may perceive that the knowledge held by them is superior to the knowledge held by a low-power unit. This may then lead them to share more of their superior knowledge with the low-power unit members who, according to them, possess inferior knowledge (Frenkel, 2008). Expertise and value of knowledge held by a source is an important consideration for seeking knowledge from the source (Borgatti \& Cross, 2003). Members of a low-power unit are more likely to seek knowledge from a high-power unit than from a low-power one. Due to knowledge sharing by the high-power unit members, and knowledge seeking by low-power members, knowledge flows tend to move from individuals from the high-power unit to individuals from the low-power unit.

Knowledge inflow to a high-power unit is less likely due to unit members engaging in less knowledge seeking to avoid entering a dependency relationship, which gives rise to power in MNEs (Mudambi, Piscitello, \& Rabbiosi, 2014). By seeking help, the seeker acknowledges his/her dependence on the helper/advisor which makes the advisor relatively more powerful than the seeker. By acknowledging incompetence and dependence, the seeker puts him/herself at a relatively power-less position compared to the advisor. This help-seeking behaviour has implications for power (Lee, 1997), which makes a subsidiary vulnerable to losing power in the MNE.

Dynamics of power in an MNE impact subsidiary managers' socio-political interactions such as knowledge sharing with peer subsidiary managers through which they try to exert and develop power for themselves or their subsidiary (Dörrenbächer \& Gammelgaard, 2011). Individuals in susbidairies use their social and political skills in micro-level interactions to enhance their susbidiary's influence. These interactions are mechanisms to building relationships, they showcase or reinforce certain valuable susbidiary charatericstics and draw attention from headquarters (Conroy, Collings, \& Clancy, 2018). As knolwedge is a source of power, such micro-political behaviour leads to more interpersonal knowledge inflows to the low-power unit from the high-power unit. Individuals from a high power subsidiary are less likely to seek knowledge as it creates dependency and leads to a loss of power (Mudambi, Piscitello, \& Rabbiosi, 2014). Similarly, they are more likely to share knowledge as it enhances their power.

Based on above discussion, we hypothesize that: 
H1a: Perceived subsidiary power has a negative direct effect on interpersonal knowledge seeking.

H1b: Perceived subsidiary power has a positive direct effect on interpersonal knowledge sharing.

\subsection{The mediating role of organizational identification}

Social identity theory (Tajfel, 1978; Turner, 1975) helps explain how organizational identification (OI) acts as a mechanism in subsidiary power - interpersonal knowledge transfer relationships. OI is an important form of social/group identification for an MNE as MNEs can be identified as social groups. Thus, an individual who is part of an organization like an MNE subsidiary, builds a perception about his/her identity based on the characteristics of the organization (e.g. subsidiary power) (Dutton et al., 1994).

The relative power of the subsidiary can become a key driver of organizational identification and lead to social categorization and stereotyping within the MNE (Hornsey, Spears, Cremers, \& Hogg, 2003). Various researchers have found that power effects selfcategorization (Smith, Smallman, \& Rucker, 2016), and inter-group relations (Hornsey et al., 2003). The more attractive the construed external image or the perceived external prestige, as with a more powerful subsidiary, the greater the organizational identification of the employees (Bartels et al., 2007; Dutton et al., 1994; Smidts, Pruyn, \& Van Riel, 2001). Power contributes to the distinctiveness and prestige of the subsidiary in the multinational which confers an employee affiliated to that subsidiary with enhanced organizational identification in his/her interactions with the out-groups or other subsidiaries or parent. Because of OI-based selfcategorization, individuals try to verify and maintain their self-conceptions of the power of their and other subsidiaries and engage in behaviour (e.g. knowledge transfer) that is consistent with this self-conception (Fiol, O'Connor, \& Aguinis, 2001).

Organizational identification acts as a mechanism in the relationship between subsidiary power and an individual's knowledge transfers because of reasons associated with identification such as self-enhancement and status protection (Terry \& Hogg, 1996). Selfenhancement is the desire to see oneself or one's actions, attitudes, and traits in a positive light (Pfeffer \& Fong, 2005). Through association and building relationships with the more powerful, individuals enhance their status (Pfeffer \& Fong, 2005). Pfeffer and Fong (2005), in their study on self-enhancement and its relation to power processes, posit that people prefer to associate themselves with winners, with successful people or more powerful ones, to feel positive about themselves and enhance their self-image. This is like 'opportunity focused 
personal identification', according to which, when an individual sees a chance to uphold or enhance his/her current identity through identifying with another individual, he/she will do so (Ashforth, Schinoff, \& Rogers, 2016). Thus, by identifying and building a relationship with a powerful subsidiary, a subsidiary member tries to enhance the power and status of his/her own subsidiary. Therefore, individuals choose to seek knowledge from high-power subsidiary members rather than low-power.

As per the status protection logic, group members who already have a positive social identity will strive to maintain the status quo (Tajfel \& Turner, 1979). Members of a subsidiary with high power will tend to maintain the powerful image by not seeking knowledge from a low-power subsidiary. By seeking help, members acknowledge that they are incompetent, or that there is a gap in their knowledge and expertise (Ames \& Lau, 1982; Karabenick \& Knapp, 1988). Showing off their knowledge gap or incompetency causes them to fear losing power, as knowledge and expertise are one of the primary sources of power (French \& Raven, 1968; Lee, 1997). This counters their need for self-enhancement, which is detrimental to the knowledge seeker's need to create a positive public impression about himself/herself (Leary \& Kowalski, 1990; Lee, 1997; Schlenker \& Weigold, 1992) and the need to maintain his or her positive self-image (Cialdini \& De Nicholas, 1989). On the other hand, seeking knowledge from the powerful party is favourable for self-enhancement, as individuals are willing to subjugate their interests and emotions in order to associate with the powerful (Pfeffer \& Fong, 2005).

Thus, based on the status protection and status enhancement logics of OI, we can argue that OI acts as a mechanism to translate subsidiary power to knowledge transfer. Also, knowledge sharing provides an opportunity to the knowledge holder to show off his/her knowledge and capabilities and differentiate him/herself from others, which can bring power and status. The need for status can drive the sharing of knowledge and expertise (Park, Chae, $\&$ Choi, 2017). This leads to lesser inflow and more outflow of interpersonal knowledge to and from a high-power unit due to the unit members engaging in less knowledge seeking and more knowledge sharing.

Based on the above discussion, we hypothesize that, H2a: Perceived subsidiary power has a negative indirect effect on interpersonal knowledge seeking mediated through organizational identification.

H2b: Perceived subsidiary power has a positive indirect effect on interpersonal knowledge sharing mediated through organizational identification. 


\subsection{The moderating effect of cultural intelligence}

Given the recent surge in interest in cultural intelligence, calls to examine its moderating effects in various settings (Ott \& Michailova, 2018; Rockstuhl \& Van Dyne, 2018) and its significance in achieving success while dealing with people from other countries and cultures (Sharma, 2019), we focussed on examining its moderating effects on the subsidiary power interpersonal knowledge transfer relationships as hypothesised above.

"Cultural intelligence refers to a person's capacity to adapt to new cultural settings based on multiple facets including cognitive, motivational and behavioural features" (Earley, 2002, p. 271). Thomas et al. (2015) define cultural intelligence (CQ) as a form of intelligence or an individual's ability to effectively interact and also adapt to a foreign culture utilizing one's cultural knowledge, cross-cultural skills and cultural metacognition, which then translate into culturally appropriate behaviour. The role of CQ in achieving organizational outcomes and leadership effectiveness is well established and has received recent attention (Ott \& Michailova, 2018; Sharma, 2019).

A higher employee CQ has a positive influence on cross-cultural knowledge transfers in an MNE (Vlajčić et al., 2019). CQ increases cultural knowledge and awareness, helps individuals to understand others' cultural preferences, and intrinsically motivates engagement in cross-cultural interactions that lead to increased knowledge sharing (Chen \& Lin, 2013). Individuals with high CQ are less likely to hide knowledge from culturally different groups as they don't engage in social categorization due to cultural differences (Bogilović, Černe, \& Škerlavaj, 2017). Therefore, the CQ of an employee is likely to influence the relationship between perceived subsidiary power and knowledge transfers which is due to the employee's organizational identification.

Interpersonal knowledge transfers between subsidiaries are likely to involve individual cross-cultural interactions. Cultural skills are very important for individuals who engage in any inter-unit interactions in an MNE (Barner-Rasmussen, Ehrnrooth, Koveshnikov, \& Mäkelä, 2014). Employees who have higher CQ are more motivated to interact with culturally different others. They have greater understanding and respect for the culture and values of others, while employees with low CQ engage in stereotyping (Kim \& Van Dyne, 2012). Their understanding of key cultural differences makes them overcome any prejudices to collaborate with others from different cultures (Ang \& Van Dyne, 2008). They are better able to discover international opportunities and be innovative (Lorenz, Ramsey, \& Richey, 2018). Cultural knowledge enhances the creativity of individuals as they can draw on culture-related novel ideas from their culturally diverse networks (Chua, Roth, \& Lemoine, 2015). 
This capacity to identify and the ability to tap opportunities in a multicultural environment helps high CQ employees transcend organizational boundaries created by their subsidiary identification and power. They have intrinsic willingness to learn from crosscultural challenges. They are less risk averse, initiative taking, and promote cooperation that has a positive impact on innovation in a multi-cultural context (Elenkov \& Manev, 2009). Their capability to initiate efforts to source and integrate resources helps them overcome inhibitions to engage in cross-border knowledge seeking from culturally different MNE members.

Cultural differences give rise to social categorization where individuals engage in ingroup out-group distinction with culturally different MNE members. Higher CQ is positively related to sharing knowledge in multi-cultural teams (Chen \& Lin, 2013). High CQ individuals are less likely to engage in culture induced social categorization and knowledge hiding (Bogilović, Černe, \& Škerlavaj, 2017). They understand diverse cultural backgrounds and values of culturally different people well and can engage in 'cultural perspective taking' (Lee, Adair, \& Seo, 2013; Mor, Morris, \& Joh, 2013). 'Cultural perspective taking' is the ability to understand how a person's cultural background may influence his/her response to a situation. This helps develop shared values and understanding and facilitates coordination and cooperation among culturally diverse MNE members who endorse similar guiding principles (Adair, Hideg, \& Spence, 2013). High CQ improves cross-cultural interpersonal communication which is indispensable for any type of creative collaboration (Chua, Morris, \& Mor, 2012).

A higher CQ enhances both knowledge seeking and sharing with culturally different others. A high-power subsidiary member with a high $\mathrm{CQ}$ will be motivated to acquire knowledge from another subsidiary member when he/she identifies a potential knowledge source. The negative effect of subsidiary power on knowledge seeking will be mitigated as a high CQ individual has a cooperative mindset that motivates him/her to interact with people from different cultures (Imai \& Gelfand, 2010). Also, the positive effect of power on knowledge sharing will be strengthened as a high CQ individual is able to overcome any inhibition that may lead him/her to share less or hide knowledge from members outside the subsidiary. These high CQ individuals are open-minded, curious, and they enjoy learning new things and interactions with people from different cultures. So, they are less likely to maintain strong in-group out-group distinctions based on subsidiary power or their identification with the subsidiary. Thus, while the negative effect of subsidiary power on seeking will be weakened, the positive effect on sharing will be strengthened by higher CQ.

Based on the above discussion, we hypothesise that, 
H3a: Cultural intelligence weakens the negative indirect relationship between perceived subsidiary power and interpersonal knowledge seeking.

H3b: Cultural intelligence strengthens the positive indirect relationship between perceived subsidiary power and interpersonal knowledge sharing.

Based on the above discussion the proposed conceptual model is shown in Figure 1.

\section{---- Figure 1 about here ----}

The proposed model (Figure 1) controls for age, tenure, education, and task interdependence, subsidiary size, cultural distance and geographic distance. Individuals of similar age, tenure or education level often share similarity in their work, personal, and educational experiences which may facilitate knowledge transfers between them (Haas \& Cummings, 2015). These individuals are more likely to share similar values and attitudes due to shared experiences in the work organization which makes it easy for them to communicate. Task-based interdependence between the respondent and the contacts is controlled so that the dependent variable captures voluntary knowledge seeking and sharing. This accounts for the extent to which the respondent and the contacts were required to communicate about any formal task (Haas \& Cummings, 2015). Subsidiary size is a firm-level control variable and controls for the size effects. Cultural distance and geographic distance variables control for the effect of institutional distance between the subsidiaries under study. We did not control for the industry effects as these are offset by accounting for only R\&D subsidiaries of MNEs.

\section{Method}

\subsection{Sampling frame and strategy}

The sampling frame consists of employees working in R\&D subsidiaries of foreign MNEs in India. $R \& D$ subsidiaries provide an appropriate environment because of the higher frequency and amount of knowledge transfer and engagement of bench level scientists or employees in knowledge seeking and sharing (Kachra \& White, 2008). To ensure that the response is representative of the employees in the subsidiary, not the unit manager, we excluded individual employees who are members of the top management (Schrader, 1991). We also chose only those MNEs that had more than two R\&Ds in separate countries to make sure that the respondents had more than one other R\&D to engage in knowledge transfers. Also, wholly owned subsidiaries were targeted over joint ventures, alliances or other forms of partnerships as they facilitate more intra-MNE knowledge inflows and outflows (Buckley \& Carter, 2003; Frost \& Zhou, 2005). 
We adopted a non-probability sampling approach of purposeful convenience sampling (Hair, Celsi, Money, Samouel, \& Page, 2015) because the target respondents need to meet the set specification of working as a researcher/scientist/engineer in R\&D at a foreign MNE in India. These R\&D units are considered at par with those in the US, Europe or any other advanced country (Motohashi, 2015). R\&Ds of MNEs were selected from the United States Patent and Trademark Office (USPTO) list of multinational organizations which were granted patents originating from India during the period from $2011-2015\left(31^{\text {st }}\right.$ Dec $)$. The data collection took place in 2017-2018.

\subsection{Data collection}

We collected data using a questionnaire survey in two stages. In the first stage of the data collection, we contacted and presented our study to the top management of these R\&Ds to request participation from their employees. A drop-and-collect survey using paper questionnaires was used which resulted in 193 responses. In the second stage of the data collection, we targeted respondents directly. As no formal database of R\&D employees was available, the target respondents were searched online through the professional networking site 'LinkedIn'. The respondents were identified through their profile description on LinkedIn which matched the required target respondent sample profile. Key words used to conduct the search included the name of the MNE R\&D, job titles: researcher/engineer/scientist/R\&D manager. An online survey questionnaire resulted in an additional 140 responses.

For both stages of the survey collection, we used the name generator technique (Cross \& Cummings, 2004; Mäkelä \& Brewster, 2009; Reagans \& McEvily, 2003). This is in line with the objective, which was to identify the contact, in another subsidiary, from whom the individual receives knowledge and the one with whom he/she shares knowledge. This helped identify the contacts with whom the respondent had engaged in information and know-how transfer (seeking and sharing), during the previous 12 months through email, telephone, video conferencing, or face-to-face meetings. Once the respondent identified the contacts, the rest of the questions in each section referred to that contact.

This process resulted in questionnaire survey data from $333 \mathrm{R} \& \mathrm{D}$ employees from 40 different R\&D subsidiaries across different MNEs headquartered in 11 different countries. Sample characteristics are presented in Table 1. The respondents primarily worked as engineers, scientists or researchers at these $R \& D$ s and held job titles such as engineer, senior engineer, chief engineer, manager, technology specialist, technology manager, etc. All the respondents were Indian nationals. 


\subsection{Measures}

In addition to the relevant control variables, the main variables of interest include interpersonal knowledge transfer (dependent variable), subsidiary power (independent variable), organizational identification (mediator) and cultural intelligence (moderator). A full list of the survey questions to measure the variables of interest along with literature sources is presented in Appendix 1.

Interpersonal knowledge transfer involves two activities: knowledge seeking and knowledge sharing (Reinholt, Pedersen, \& Foss, 2011). Therefore, both the activities of seeking and sharing are examined separately to understand individual knowledge inflows/outflows or transfers to and from the focal subsidiary. Knowledge transfer (seeking/sharing) is a composite measure of the amount and use of knowledge that the respondent received and shared through seeking and sharing respectively. Following Mäkelä and Brewster (2009) as adapted from Hansen (2002) and Kogut and Zander (1992), knowledge is captured by items that include 'facts or information', 'advice', 'personal insights' and 'tricks of the trade'.

Following Najafi-Tavani et al. (2015) and Ambos et al. (2010), the power of a subsidiary is defined by its influence over HQs' decisions and its autonomy. We adapted these subsidiary-level measures to represent the perception of bench-level employees. The construct 'Subsidiary Power' is a formative measurement construct (Coltman, Devinney, Midgley, \& Venaik, 2008). It is a composite measure (Borsboom, Mellenbergh, \& Van Heerden, 2004), an average of the items - 'influence' and 'autonomy'. For this study, 'subsidiary power' means the perceived relative power of the own subsidiary of the respondent compared to the contact's subsidiary, calculated by subtracting the contact's subsidiary power from the power of the respondent's subsidiary. A positive value indicates a higher power and a negative value indicates a lower power of the respondent's subsidiary with respect to that of the contact subsidiary.

Organizational identification (OI) was measured on a five-point Likert scale adopted from Reade (2001) and Smale et al. (2015). These items assessed how much the employees identified with their local unit/subsidiary. Cultural intelligence (CQ) was measured using the ten item five-point Likert scale measure developed by Thomas et al. (2015). Following Thomas et al.'s (2015) measure of CQ, the first-order observed constructs, Metacognition, Skill and Knowledge, were used to measure the second-order construct, CQ. 
Among the control variables, age is measured by whether the respondents in $R \& D$ subsidiaries in India are younger (0) or older (1) than their counterparts with whom they are sharing or seeking knowledge. Tenure is measured as the number of years worked at the subsidiary. Education is measured as undergraduate (0) and postgraduate and above (1) Task dependency is measured, on a 5-point scale, as the extent to which the respondent and the contacts were required to communicate about any formal task (Haas \& Cummings, 2015). Subsidiary size is measured as log of number of employees. Cultural distance is measured by Kogut and Singh's (1988) composite index measure. Geographic distance is measured as the $\log$ of physical distance in kilometres between the city locations of the subsidiaries whose employees are engaged in knowledge seeking and sharing.

\section{Analysis and results}

As the 333 survey responses were collected in two stages (193 paper-based survey, 140 online survey) we examined the survey bias between these two stages before undertaking data analysis. Using two different methods for the survey was necessary to increase the response rate. To assess any response bias resulting from this difference in survey method, an independent sample t-test was conducted. It compared the responses of items of the dependent variable, knowledge seeking and knowledge sharing, for the two surveys. Out of the sixteen items for knowledge seeking and sharing (eight each), only four items were found to be different ( $p>0.05$ ) for the paper-based vs the online survey. Therefore, we can safely argue that the threat of response bias does not exist.

\subsection{Confirmatory factor analysis}

Confirmatory factor analysis (CFA) was conducted separately for the two models, knowledge seeking and knowledge sharing (Table 2). The construct CQ is a second-order construct which is a composite of three first-order constructs, knowledge, metacognition and skill (Thomas et al., 2015). Similarly, the constructs knowledge seeking and sharing are also second-order constructs which are composites of the observed constructs, amount and use of knowledge received and shared.

\section{----Insert Table 2 about here----}

All item loadings in the two models (seeking and sharing) were greater than 0.56 and 0.57 respectively, with most of them exceeding 0.71 with significance at .000 level (Byrne, 2010) in both the models. Both the models have good model fit as is indicated from CMIN/DF, CFI, RMSEA, PCLOSE, TLI, NFI, and IFI values as shown in Table 2 (Byrne, 2010; Hair, 
Black, Babin, \& Anderson, 2010; Hu \& Bentler, 1999). The final second-order models for both seeking and sharing have the lowest Akaike Information Criterion (AIC) value compared to the previous models (Burnham \& Anderson, 2004).

Construct Reliability for all the latent factors is greater than 0.70 (Fornell \& Larcker, 1981). Also, Cronbach's $\alpha$ is greater than 0.70 (Hair et al., 2015) for all the scales except the first order factors CQ knowledge (0.65) and CQ Metacognition (0.69) in both the seeking and sharing models. Values ranging between 0.60 and 0.70 exhibit moderate strength of association and are acceptable (Hair et al., 2015, p. 255). For convergent validity, the Average Variance Extracted (AVE) values for all the latent constructs in both the knowledge seeking and sharing models have been found to be greater than the acceptable criteria of 0.50 (Fornell \& Larcker, 1981; Hair et al., 2010). We established the discriminant validity of the constructs since the square-root of the AVE by each construct is greater than the correlation between all pairs of constructs (Table 3) and all AVEs are greater than Maximum Shared Variances (MSVs) (Hair et al., 2010).

\section{----Insert Table 3 about here ----}

Table 3 shows the means (M), standard deviations (SD), and bivariate correlations of all variables. The diagonal bold values are the square root of the AVE of the constructs. As expected, the dependent variable knowledge seeking had significant positive correlations with organizational identification $(\mathrm{r}=.16, \mathrm{p}<.01)$, and cultural intelligence $(\mathrm{r}=.33, \mathrm{p}<.01)$. Knowledge sharing had significant positive correlations with subsidiary power $(\mathrm{r}=.18, \mathrm{p}<.01)$, organizational identification $(r=.11, \mathrm{p}<.05)$, and cultural intelligence $(r=.41, \mathrm{p}<.01)$.

\subsection{Second stage moderated mediation results}

We tested the proposed second stage moderated mediation or moderated indirect effects model using Conditional Process Analysis with PROCESS macro (Hayes, 2013; Hayes, 2018). For observed variable models, the results are unaffected whether the maximum likelihood based structural equations modelling (SEM) or PROCESS is used (Hayes, 2018, p.527). However, PROCESS is relatively easier to use if the proposed model includes both mediation and moderation of indirect effects and fits with the PROCESS models. On the other hand, structural equations modelling (SEM) gives more flexibility to analyse data. As our proposed moderated mediation or moderated indirect effects model fits very well with PROCESS models (Model numbers 4 and 14), we utilised PROCESS to analyse our model. We apply 5000 bootstrap samples, which is considered sufficient (Hayes, 2018). 
To test the proposed conceptual model we examine the following conditions: 1) the direct effect of subsidiary power on knowledge seeking and sharing; 2) the mediation effect of identification on the relationship between subsidiary power and knowledge seeking and sharing; and 3) the conditional indirect effect of subsidiary power on knowledge seeking and sharing through OI, depending on the degree of CQ. All the results are presented in Table 4 and Table 5.

\section{----Insert Table 4 and Table 5 about here----}

To test the direct and indirect effect of subsidiary power on interpersonal knowledge transfer, we have used Process Model 4 which is the mediation model (Table 4). While the effect of subsidiary power on knowledge sharing was found to be positive and significant, $\beta$ $=0.102, \mathrm{p}=.003,95 \% \mathrm{CI}: 0.036-0.169(\mathrm{CI}=$ Confidence Interval $)$; the effect on knowledge seeking was found to be positive and non-significant, $\beta=0.059, \mathrm{p}=0.309,95 \% \mathrm{CI}$ : -0.554 0.174. Thus, H1b (positive direct effect of subsidiary power on knowledge sharing) is supported while H1a (negative direct effect of subsidiary power on knowledge seeking) is not supported.

From the PROCESS Model 4 output, we found evidence of an indirect mediation effect for the relationship of subsidiary power and knowledge seeking through organizational identification, $\beta=0.02295 \% \mathrm{CI}$ : 0.002 - 0.052 (H2a). The confidence interval does not contain zero, which proves that organizational identification mediates the relationship. Mediation is found but the indirect effect is positive as compared to the hypothesised negative effect. Thus, $\mathrm{H} 2$ a findings are significant but contrary to the hypothesis. We did not find evidence of an indirect mediation effect of subsidiary power on knowledge sharing through organizational identification $\beta=0.00795 \%$ CI: $-0.004-0.028$, as the CI contains zero (H2b not supported). The effect size of the indirect mediation of subsidiary power on knowledge seeking is 0.025 (partially standardized) and 0.022 (completely standardized). The effect size of the direct effect of subsidiary power on knowledge sharing is 0.101 . The average effect size in international business research is small (Ellis, 2010).

We used PROCESS model 14 to assess the conditional indirect effect of subsidiary power on knowledge seeking and sharing through OI, depending on the degree of CQ. Our model is a second-stage moderated mediation model as moderation by CQ takes place in the second stage of the mediation. The interaction effect of CQ and OI on knowledge seeking is found to be positive and significant $\beta=0.924 \mathrm{p}=0.02,95 \% \mathrm{CI}: 0.144-1.704$. H3a, which is the moderated mediation effect of CQ on the indirect effect of subsidiary power on knowledge seeking is positive and significant, $\beta=0.07695 \% \mathrm{CI}: 0.003-0.178$. Hypothesis $\mathrm{H} 3 \mathrm{a}$ was that 
cultural intelligence will weaken the negative effect of subsidiary power on knowledge seeking. But, as per the finding, subsidiary power has a positive effect on knowledge seeking and cultural intelligence strengthens this effect. Thus, we can conclude that H3a is supported. The interaction effect of CQ and OI on knowledge sharing is positive but non-significant $\beta=0.217$ $\mathrm{p}=0.32,95 \% \mathrm{CI}:-0.214-0.648$. H3b, which is the moderated mediation effect of CQ on the effect of subsidiary power on knowledge sharing is found to be non-significant $\beta=0.007,95 \%$ CI: -0.082 - 0.088. Thus, H3b is not supported.

Figure 2 shows the moderated mediation effect of cultural intelligence on knowledge seeking to probe the level at which the moderation is significant. This graph is generated manually based on the Johnson-Neyman technique (Hayes, 2018, p.253) values generated by PROCESS. We find that the conditional effect of subsidiary power is moderated by cultural intelligence when cultural intelligence is very high $(\geq 0.291)$ or very low $(\leq-0.637)$. The used latent variables (cultural intelligence, knowledge seeking and sharing and organizational identification) were mean-centred in the analysis.

Among the control variables, we find (Table 4) that Tenure has a positive highly significant effect on organizational identification, knowledge seeking and sharing. Education is found to have positive significant effect on organizational identification. Age has a negative significant effect on knowledge seeking, and task dependency has a negative significant effect on knowledge sharing.

\subsection{Robustness of the results}

To ensure the robustness of the results we paid attention to common method bias and endogeneity. Endogeneity can be caused by omitted variables and simultaneity (Rocha, van Praag, Folta \& Carneiro, 2019). Simultaneity occurs when "two or more variables simultaneously cause each other" (Rocha et al., 2019 p.745). We have addressed this by using established measurement items (see Appendix 1) and testing a rival model using knowledge transfer (seeking and sharing) as the independent variable and subsidiary power as the outcome variable. The results in the main model are stronger than the results in the rival model. For example, R-square is much higher in the main model (knowledge seeking 19\%, knowledge sharing $25 \%$ ) as compared to the rival model where it was reduced to $4 \%$ and $10 \%$ respectively. Also, some results (e.g. subsidiary power - knowledge seeking relationships) became nonsignificant in the rival model. We also included relevant individual-level and organizationallevel control variables to eliminate alternative explanations. Based on theoretically informed 
measurements and causal relationships, appropriate control variables, and testing a rival model, we believe that our findings are safe from the endogeneity threat.

To minimize the potential threat of common method bias (CMB), we have used some ex ante and ex post approaches (Chang, Witteloostuijn, \& Eden, 2010). At the design stage, we mixed the order of questions. Respondents were assured of the anonymity and confidentiality of the study by making respondents unidentifiable if they wished. Moreover, as our model is complex (moderated mediation) it is unlikely for respondents to visualize interactive effects. As an ex post approach, we used two statistical approaches. At first, we used Harman onefactor analysis and later used Lindell and Whitney's (2001) partial correlation technique using a marker variable (Malhotra, Kim, \& Patil, 2006), "Fashion Consciousness". The Harman onefactor test reveals that the percentage of variance accounted for by the largest single factor is $10.17 \%$ in the knowledge seeking model and $11.46 \%$ for the knowledge sharing model, which are below the 50\% threshold. Eigenvalues for all the factors were found to be greater than 1 . Additionally, following Lindell and Whitney (2001), we checked the correlations and partial correlations for the variables measured with perceptual measures. This is in line with Malhotra et al. (2006), Najafi-Tavani, Giroud, and Sinkovics (2012) and Noorderhaven and Harzing (2009). First, we inspected each variable's zero-order correlation for statistical significance. Later, the partial correlation between the variables controlling for the marker variable, "Fashion Consciousness" was checked. It was found that all the significant zero-order correlations for the variables remained significant for the partial correlations, which implies that the findings are safe from the threat of CMB.

\section{Discussion and conclusion}

Based on our research question on the effect of employees' perceived subsidiary power on interpersonal intra-MNE knowledge transfer within an MNE, we proposed a direct and indirect effect of subsidiary power on knowledge seeking (H1a - direct negative, H2a - indirect negative) and knowledge sharing ( $\mathrm{H} 1 \mathrm{~b}$ - direct positive, $\mathrm{H} 2 \mathrm{~b}$ - indirect positive). We also proposed that cultural intelligence weakens the negative indirect relationship between subsidiary power and knowledge seeking $(\mathrm{H} 3 \mathrm{a})$ and strengthens the positive relationship between them (H3b). We find significant results for H1b, H2a and H3a. Primarily, the key findings suggest that perceived subsidiary power has a significant positive direct effect on knowledge sharing and a significant indirect effect, through organizational identification, on knowledge seeking. Further, cultural intelligence moderates the effect of organizational identification on knowledge seeking as well as the indirect effect of perceived subsidiary power 
on knowledge seeking. It strengthens the positive effects on knowledge seeking. The findings highlight the role of organizational identification and cultural intelligence in explaining the impact of perceived subsidiary power on interpersonal knowledge transfer within the MNE.

\subsection{Theoretical implications}

The underlying theoretical insights for the impact of subsidiary power on knowledge transfer (H1 and H2) are drawn from social identity theory (Tajfel, 1978; Turner, 1975). Based on their organizational identity with their subsidiaries, subsidiary employees are expected to engage in knowledge transfer in a way that reflects their subsidiary's perceived relative power in comparison to the subsidiary with which they engage in knowledge transfer. Further, the knowledge-based view argues that the knowledge resides in individuals (Grant, 1996) and thus individuals' perceptions of their subsidiary power and cognitive skills (e.g. cultural intelligence) are critical in their interpersonal interactions and knowledge transfer behaviour.

The findings of a significant direct positive effect of subsidiary power on knowledge sharing (H1b) and a significant indirect positive effect on knowledge seeking (H2a) can be interpreted from two angles. Firstly, both $\mathrm{H} 1 \mathrm{~b}$ and $\mathrm{H} 2 \mathrm{a}$ findings indicate that subsidiary power has positive indirect-only mediation effects on knowledge seeking and direct-only nonmediation effects on knowledge sharing (Zhao, Lynch, \& Chen, 2010). That is organizational identification acts as a mechanism for knowledge seeking but we did not find such evidence for knowledge sharing. Secondly, contrary to our hypothesis $(\mathrm{H} 2 \mathrm{a})$, the indirect effect of subsidiary power on knowledge seeking through identification is found to be positive. This may be due to the cultural context of India. Traditionally, India is a high power distance country where people have respect and acceptance of hierarchy and power differences (Chhokar, 2007). In a high power distance society, low power members are found to rely less on vertical sources for guidance (Hwang \& Francesco, 2010). Additionally, this positive relationship may also be due to the Indian culture being more performance oriented (Chhokar, 2007; House, Dorfman, Javidan, Hanges, \& de Luque, 2013). In such societies, innovation, high standards and performance improvement are encouraged and rewarded. So, when Indians identify with a high-power subsidiary, their orientation to high performance and competitiveness encourages them to strive for improving their performance and maintain their high power status by seeking more knowledge to meet their demands for knowledge and information to accomplish their work. These cultural contextual explanations also explain why older individuals, compared to their younger counterparts, seek less knowledge. 
The positive direct effect of CQ on knowledge seeking and its role in strengthening the positive indirect effect of subsidiary power is due to employees engaging in more knowledge seeking. Because of CQ, employees can easily overcome any hesitation to interact with members of other subsidiaries. Such a positive effect is in line with the literature on CQ's effects on knowledge transfer (Chen \& Lin, 2013; Vlajčić et al., 2019). Higher CQ not only increases and makes cross-cultural communication easier, but also more effective. Therefore, a member of a low-power subsidiary can conquer any inhibition that arises due to their identification with their subsidiary and experience of high power distance and thereby engage more in knowledge seeking. Similarly, knowledge seeking by a high-power member will also increase as communication improves due to better understanding and less ambiguity in the knowledge transfer relationship. Thus, the effect of subsidiary power on knowledge seeking through identification is stronger in the presence of CQ.

By examining cross border individual knowledge transfer in the MNE, this study advances our understanding about individual knowledge transfer behaviour as well as knowledge transfers at the organizational level, as individual transfers are the microfoundations of organizational-level knowledge transfers (Grant, 1996; Schotter et al., 2017). We probed and identified an internal boundary, an organizational contextual factor, subsidiary power, which emerges due to the organizational separation of the MNE. For this, we drew on social identity theory (Tajfel, 1978; Turner, 1975) and the knowledge-based view (Grant, 1996). Our findings suggest that subsidiary power affects individual knowledge transfer decisions and thus the dynamics of lateral collaboration within MNEs across subsidiaries. Most of the literature has examined the impact of subsidiary power on organizational-level knowledge transfer (Wong et al., 2008; Whittle et al., 2016). We demonstrate how individuals' perception of their subsidiary power influences individual-level knowledge transfer behaviour. Understanding individual-level knowledge transfer behaviour is important because of heterogeneity in individual behaviour (Felin \& Hesterly, 2007) and that most of the tacit knowledge resides in individuals (Grant, 1996).

We suggest that subsidiary power is a form of knowledge governance mechanism, which can be categorised into formal or informal mechanisms (Foss, Husted, \& Michailova 2010). Formal governance mechanisms such as HRM practices or knowledge management tools are direct control mechanisms that require less perception management. They are transaction-based mechanisms under the control of the MNE (Husted, Michailova, Minbaeva, \& Pedersen, 2012). Informal or indirect control mechanisms like organizational culture or values need more perception management as they are intended to enhance employee 
commitment and their knowledge transfer behaviour. However, subsidiary power, like other formal mechanisms, is not entirely determined or influenced by the focal subsidiary but is dependent on other external actors (Dörrenbächer \& Gammelgaard, 2011). It can be a formal mechanism when the MNE conspicuously grants power and autonomy to a subsidiary through mandates of knowledge creation or transfer (Ciabuschi, Martín, \& Ståhl, 2010). However, unlike a formal factor it is semi-permanent in nature and harder to change for a subsidiary (Foss et al., 2010). Therefore, we call it an identity-based quasi-formal knowledge governance mechanism. Employees' organizational identification or their perception of the identity-based factor can be used to influence knowledge sharing behaviour that requires higher levels of perception management. Thus, we add to the knowledge governance approach (Foss, 2007) by bringing in an organizational-level, identity-based antecedent for governing individual knowledge transfer behaviour in an MNE.

Additionally, we brought in a relevant individual-level competency factor, cultural intelligence, which was found to have an influence on individual knowledge transfer behaviour. The positive influence of CQ on knowledge transfer is accepted in the literature (Vlajčić et al., 2019). We extend the literature by highlighting the moderating role of CQ on interpersonal knowledge transfer behaviour. Moreover, we believe that by treating knowledge transfers as primarily sharing, most of the literature provided a fragmented view of the process. As knowledge seeking and sharing are two distinct activities, we examined them separately. The findings also substantiate this standing as the impact of factors on knowledge seeking are found to be different from those of knowledge sharing.

The study also helped us gain understanding of the knowledge transfer behaviours of Indian employees. We observed that the organizational behaviour of Indian employees was influenced to a great extent by the national culture. Collectivist culture is found to be an important antecedent of organizational identification (Baker, Carson, \& Carson, 2009). Due to high in-group collectivism of Indian culture (Chhokar, 2007), loyalty and identification with the organization is high. As found, they are more likely to draw on salient distinctive characteristics of their subsidiary, such as power. When it comes to seeking knowledge from another subsidiary, which is equivalent to seeking help, the power of their subsidiary impacts their decision due to their identification with their subsidiary.

\subsection{Managerial relevance}

As suggested by Foss et al. (2010), to gain maximum benefit from knowledge sharing, it is crucial that managers and decision makers be aware of different situations, as well as the 
appropriate governance mechanisms that may be deployed to achieve the desired knowledge sharing behaviour. Our findings suggest that managers should consider the power of subsidiaries to govern individual knowledge transfers across subsidiaries. HQ managers can use this as the HQ can formally endow the subsidiary with power through mandates, resource allocations or rights in MNE decision making, or even divest a subsidiary of its power. On the other hand, subsidiary managers, who cannot change the power of their or another subsidiary, can use perception-based management techniques to influence employees' perceptions of power and organizational identification. This can be done through focused discussions around the role of a subsidiary, or by implementing effective socialization mechanisms (Birkinshaw, Holm, Thilenius, \& Arvidsson, 2000). Managers can enhance the organizational identification of their employees by communicating to them about organizational successes, goals and values, or through international assignments to help them enhance their identity with the superordinate authority, the MNE (Richter, West, Van Dick, \& Dawson, 2006).

Likewise, the CQ of employees can be increased through training and development (Earley \& Mosakowski, 2004) to enhance their cross-cultural skills and interpersonal knowledge transfer behaviour. To strengthen and achieve higher knowledge transfers across borders, managers can focus on developing and enhancing the CQ of their employees through culture-based training initiatives. The concepts of subsidiary power and CQ are not new to managers. However, we suggest utilising an employee's organizational identification and their CQ capabilities in managing interpersonal inter-subsidiary (cross-border) knowledge transfer behaviour. Thus, we draw their attention to this identity-based quasi-formal knowledge governance mechanism (perception of their subsidiary power) and individual-level characteristics (cultural intelligence) to the management of individual knowledge transfers to improve lateral collaboration in MNEs.

\subsection{Limitations and future research}

Considering the multi-level and nested nature of the variables used in the model, a multi-level research method would have been the ideal approach for this study. However, this was not possible due to difficulties with data collection. Nonetheless, it was found that the intra-class correlation of the perception-based responses was between 0.03 and 0.19 , which implies that the individual level of analysis is appropriate for this study (Smidts et al., 2001). Also, Bliese (2000) recommends that ICC values above 0.20 indicate a desirable level for aggregation of group effects (Hon \& Lu, 2015). To make data collection more feasible, information on knowledge transfer was collected from one side of the knowledge transfer relationship. 
Considering the dyadic characteristic of the variable, it would have been ideal to measure it on both sides, knowledge seeker and sharer, of the dyad (Mäkelä, Andersson, \& Seppälä, 2012).

Testing this model in a different country context, especially in a developed country, culturally different from India, may provide additional interesting insights for comparison. Investigating employee knowledge transfer with contacts from subsidiaries which are relatively equal in power, say, between two developed country subsidiaries, may result in some fascinating outcomes. Testing the model in a context like that of India (ie. in other emerging economies) would help validate the findings from India and could uncover new avenues for exploration. Future research can explore the uncharted territory of sub-cultures in India which remain greatly unexplored. Different facets of cultural intelligence and levels of organizational identification also provide ample room for exploration. Overall, it would be interesting to explore how identity based quasi-formal organizational knowledge governance mechanisms interact with other formal or informal and individual or organizational-level mechanisms to influence individual and organizational-level knowledge transfers in the organization. 


\section{References}

Adair, W. L., Hideg, I., \& Spence, J. R. (2013). The Culturally Intelligent Team: The Impact of Team Cultural Intelligence and Cultural Heterogeneity on Team Shared Values. Journal of Cross-Cultural Psychology, 44(6), 941-962.

Ambos, T. C., \& Ambos, B. (2009). The Impact of Distance on Knowledge Transfer Effectiveness in Multinational Corporations. Journal of International Management, 15(1), 1-14.

Ambos, T. C., Andersson, U., \& Birkinshaw, J. (2010). What Are the Consequences of Initiative-Taking in Multinational Subsidiaries? Journal of International Business Studies, 41(7), 1099-1118.

Ames, R., \& Lau, S. (1982). An Attributional Analysis of Student Help-Seeking in Academic Settings. Journal of Educational Psychology, 74(3), 414-423.

Ang, S., \& Van Dyne, L. (2008). Handbook of Cultural Intelligence : Theory, Measurement, and Applications. Armonk, N.Y: M.E. Sharpe.

Argote, L., \& Kane, A. A., (2009). Superordinate Identity and Knowledge Creation and Transfer in Organizations. In: Foss, N., Michailova, S. (Eds.), Knowledge Governance: Processes and Perspectives. Oxford University Press, New York, NY, pp. 166-190.

Argote, L., \& Ingram, P. (2000). Knowledge Transfer: A Basis for Competitive Advantage in Firms. Organizational Behavior and Human Decision Processes, 82(1), 150-169.

Ashforth, B. E., Schinoff, B. S., \& Rogers, K. M. (2016). “I Identify with Her,"“I Identify with Him”: Unpacking the Dynamics of Personal Identification in Organizations. Academy of Management Review, 41(1), 2860 .

Baker, D., Carson, K., \& Carson, P. (2009). An Individual-Level Examination of the Impact of Cultural Values on Organizational Identification. Journal of Applied Management and Entrepreneurship, 14(2), 29-43.

Balogun, J., Jarzabkowski, P., \& Vaara, E. (2011). Selling, Resistance and Reconciliation: A Critical Discursive Approach to Subsidiary Role Evolution in MNEs. Journal of International Business Studies, 42(6), 765786.

Barner-Rasmussen, W., Ehrnrooth, M., Koveshnikov, A., \& Mäkelä, K. (2014). Cultural and Language Skills as Resources for Boundary Spanning within the MNC. Journal of International Business Studies, 45(7), 886-905.

Bartels, J., Pruyn, A., De Jong, M., \& Joustra, I. (2007). Multiple Organizational Identification Levels and the Impact of Perceived External Prestige and Communication Climate. Journal of Organizational Behavior, 28(2), 173-190.

Bartlett, C., \& Ghoshal, S. (1989). Managing across Borders: The Transnational Solution. Boston, MA: Harvard Business School Press.

Birkinshaw, J., Holm, U., Thilenius, P., \& Arvidsson, N. (2000). Consequences of Perception Gaps in the Headquarters-Subsidiary Relationship. International Business Review, 9(3), 321-344.

Birkinshaw, J., \& Hood, N. (1998). Multinational Subsidiary Evolution: Capability and Charter Change in Foreign-Owned Subsidiary Companies. Academy of Management Review, 23(4), 773-795.

Bjerregaard, T., \& Klitmoller, A. (2016). Conflictual Practice Sharing in the MNC: A Theory of Practice Approach. Organization studies, 37(9), 1271-1295.

Björkman, I., Barner-Rasmussen, W., \& Li, L., 2004. Managing Knowledge Transfer in MNCs: The Impact of Headquarters Control Mechanisms. Journal of International Business Studies 35, 443-455.

Bliese, P. D. (2000). Within-Group Agreement, Non-Independence, and Reliability: Implications for Data Aggregation and Analysis. . In K. J. K. Klein, S. W. (Ed.), Multilevel Theory, Research and Methods in Organizations: Foundations, Extensions and New Directions (pp. 349-381). San Francisco: Jossey-Bass.

Bogilović, S., Černe, M., \& Škerlavaj, M. (2017). Hiding Behind a Mask? Cultural Intelligence, Knowledge Hiding, and Individual and Team Creativity. European Journal of Work and Organizational Psychology, 26(5), 710-723.

Borgatti, S. P., \& Cross, R. (2003). A Relational View of Information Seeking and Learning in Social Networks. Management Science, 49(4), 432-445.

Borsboom, D., Mellenbergh, G. J., \& Van Heerden, J. (2004). The Concept of Validity. Psychological Review, 111(4), 1061-1071.

Buckley, P. J., \& Carter, M. J. (2003). Governing Knowledge Sharing in Multinational Enterprises. MIR: Management International Review, 43(3), 7-25.

Burnham, K. P., \& Anderson, D. R. (2004). Multimodel Inference: Understanding AIC and BIC in Model Selection. Sociological Methods \& Research, 33(2), 261-304.

Byrne, B. M. (2010). Structural Equation Modeling: Perspectives on the Present and the Future. International Journal of Testing, 1(3-4), 327-334.

Caimo, A., \& Lomi, A. (2015). Knowledge Sharing in Organizations: A Bayesian Analysis of the Role of Reciprocity and Formal Structure. Journal of Management, 41(2), 665-691. 
Cano-Kollmann, M., Hannigan, T. J., \& Mudambi, R. (2018). Global Innovation Networks - Organizations and People. Journal of International Management, 24(2), 87-92.

Chang, S.-J., Witteloostuijn, A. V., \& Eden, L. (2010). From the Editors: Common Method Variance in International Business Research. Journal of International Business Studies, 41(2), 178.

Chen, M., \& Lin, C. P. (2013). Assessing the Effects of Cultral Intelligence on Team Knowledge Sharing from a Socio-Cognitive Perspective. Human Resource Management, 52(5), 675-695.

Chhokar, J. S. (2007). Culture and Leadership across the World: The Globe Book of in-Depth Studies of 25 Societies. Mahwah, N.J: Lawrence Erlbaum Associates.

Chua, R. Y. J., Morris, M. W., \& Mor, S. (2012). Collaborating across Cultures: Cultural Metacognition and Affect-Based Trust in Creative Collaboration. Organizational Behavior and Human Decision Processes, $118(2), 116-131$.

Chua, R. Y. J., Roth, Y., \& Lemoine, J.-F. (2015). The Impact of Culture on Creativity: How Cultural Tightness and Cultural Distance Affect Global Innovation Crowdsourcing Work. Administrative Science Quarterly, 60(2), 189-227.

Ciabuschi, F., Dellestrand, H., \& Kappen, P. (2012). The Good, the Bad, and the Ugly: Technology Transfer Competence, Rent-Seeking, and Bargaining Power. Journal of World Business, 47(4), 664-674.

Ciabuschi, F., Martín, O. M., \& Ståhl, B. (2010). Headquarters' Influence on Knowledge Transfer Performance. Management International Review, 50(4), 471-491.

Cialdini, R. B., \& De Nicholas, M. E. (1989). Self-Presentation by Association. Journal of Personality and Social Psychology, 57(4), 626-631.

Cohen, W.M., \& Levinthal, D.A., (1990). The Implications of Spillovers for R\&D Investment and Welfare: A New Perspective. Administrative Science Quarterly 35, 128-152.

Coltman, T., Devinney, T. M., Midgley, D. F., \& Venaik, S. (2008). Formative Versus Reflective Measurement Models: Two Applications of Formative Measurement. Journal of Business Research, 61(12), 12501262.

Conroy, K. M., Collings, D. G., \& Clancy, J. (2018). Sowing the Seeds of Subsidiary Influence: Social Navigating and Political Maneuvering of Subsidiary Actors. Global Strategy Journal, 9 (4), 502-526.

Crespo, C.F., Griffith, D.A., \& Lages, L.F. (2014). The Performance Effects of Vertical and Horizontal Subsidiary Knowledge Outflows in Multinational Corporations. International Business Review, 23, 993-1007.

Cross, R., \& Cummings, J. N. (2004). Tie and Network Correlates of Individual Performance in KnowledgeIntensive Work. Academy of Management Journal, 47(6), 928-937.

Dasí, À., Pedersen, T., Gooderham, P. N., Elter, F., \& Hildrum, J. (2017). The Effect of Organizational Separation on Individuals' Knowledge Sharing in MNCs. Journal of World Business, 52(3), 431-446.

Dörrenbächer, C., \& Gammelgaard, J. (2006). Subsidiary Role Development: The Effect of Micro-Political Headquarters-Subsidiary Negotiations on the Product, Market and Value-Added Scope of ForeignOwned Subsidiaries. Journal of International Management, 12(3), 266-283.

Dörrenbächer, C., \& Gammelgaard, J. (2011). Subsidiary Power in Multinational Corporations: The Subtle Role of Micro-Political Bargaining Power. Critical Perspectives on International Business, 7(1), 30-47.

Dutton, J. E., Dukerich, J. M., \& Harquail, C. V. (1994). Organizational Images and Member Identification. Administrative Science Quarterly, 239-263.

Earley, P. C. (2002). Redefining Interactions across Cultures and Organizations: Moving Forward with Cultural Intelligence. Research In Organizational Behavior, 24, 24, 271-299.

Earley, P.C., \& Mosakowski, E. (2004). Cultural Intelligence. Harvard Business Review, 82, 139-146.

Elenkov, D. S., \& Manev, I. M. (2009). Senior Expatriate Leadership's Effects on Innovation and the Role of Cultural Intelligence. Journal of World Business, 44(4), 357-369.

Ellis, P., (2010). Effect Sizes and the Interpretation of Research Results in International Business. Journal of International Business Studies, 41 (9), 1581-1588.

Felin, T., \& Hesterly, W. S. (2007). The Knowledge-Based View, Nested Heterogeneity, and New Value Creation: Philosophical Considerations on the Locus of Knowledge. Academy of Management Review, 32(1), 195218.

Fiol, C. M., O'Connor, E. J., \& Aguinis, H. (2001). All for One and One for All? The Development and Transfer of Power across Organizational Levels. Academy of Management Review, 26(2), 224-242.

Fornell, C., \& Larcker, D. F. (1981). Evaluating Structural Equation Models with Unobservable Variables and Measurement Error. Journal of Marketing Research 18(1), 39-50.

Foss, N.J., Minbaeva, D.B., Pedersen, T., \& Reinholt, M., (2009). Encouraging Knowledge Sharing among Employees: How Job Design Matters. Human Resource Management 48, 871-893.

Foss, N., \& Pedersen, T. (2019). Microfoundations in International Management Research: The Case of Knowledge Sharing in Multinational Corporations. Journal of International Business Studies, 50(9), 1594-1621. 
Foss, N. J. (2007). The Emerging Knowledge Governance Approach: Challenges and Characteristics. Organization, 14(1), 29-52.

Foss, N. J., Husted, K., \& Michailova, S. (2010). Governing Knowledge Sharing in Organizations: Levels of Analysis, Governance Mechanisms, and Research Directions. Journal of Management Studies, 47(3), 455-482.

French, J., \& Raven, B. (1968). The Bases of Social Power. New York: Harper \& Row: In D. Cartwright and A. Zander (Eds.), Group dynamics: Research and Theory (pp. 259-269). New York: Harper and Row.

Frenkel, M. (2008). The Multinational Corporation as a Third Space: Rethinking International Management Discourse on Knowledge Transfer through Homi Bhabha. Academy of Management Review, 33(4), 924942.

Frost, T. S., \& Zhou, C. (2005). R\&D Co-Practice and 'Reverse' Knowledge Integration in Multinational Firms. Journal of International Business Studies, 36(6), 676-687.

Grant, R. M. (1996). Toward a Knowledge-Based Theory of the Firm. Strategic Management Journal, 17(S2), 109-122.

Gregersen, H. B., \& Black, J. S. (1992). Antecedents to Commitment to a Parent Company and a Foreign Operation. Academy of Management Journal, 35(1), 65-90.

Gupta, A.K., \& Govindarajan, V. (2000). Knowledge Flows within Multinational Corporations. Strategic Management Journal, 21, 473-496.

Gupta, R., \& Gupta, B. (2014). Foreign MNC R\&D Centers in India: A Study of Their Publications, 2003-12. DESIDOC Journal of Library \& Information Technology, 34(4), 287-292.

Haas, M. R., \& Cummings, J. N. (2015). Barriers to Knowledge Seeking within Mnc Teams: Which Differences Matter Most? Journal of International Business Studies, 46(1), 36-62.

Hair, J. F., Black, W. C., Babin, B. J., \& Anderson. (2010). Multivariate Data Analysis (7th ed. ed.). Upper Saddle River, NJ: Prentice Hall.

Hair, J. F., Celsi, M., Money, A., Samouel, P., \& Page, M. (2015). The Essentials of Business Research Methods: Third Edition: Taylor and Francis Inc.

Hansen, M., T. (2002). Knowledge Networks: Explaining Effective Knowledge Sharing in Multiunit Companies. Organization Science, 13(3), 232-248.

Hansen, M.T., Mors, M.L., Lovas, B., (2005). Knowledge Sharing in Oranizations: Multiple Networks, Multiple Phases. Academy of Management Journal, 48, 776-793.

Hayes, A. F. (2013). Introduction to Mediation, Moderation, and Conditional Process Analysis a RegressionBased Approach. New York: Guilford Press.

Hayes, A. F. (2018). Introduction to Mediation, Moderation, and Conditional Process Analysis : A RegressionBased Approach (Second edition. ed.). New York: Guilford Press.

Hon, A. H., \& Lu, L. (2015). Are We Paid to Be Creative? The Effect of Compensation Gap on Creativity in an Expatriate Context. Journal of World Business, 50, 159-167.

Hornsey, M. J., Spears, R., Cremers, I., \& Hogg, M. A. (2003). Relations between High and Low Power Groups: The Importance of Legitimacy. Personality and social psychology bulletin, 29(2), 216-227.

House, R. J., Dorfman, P. W., Javidan, M., Hanges, P. J., \& de Luque, M. F. S. (2013). Strategic Leadership across Cultures: Globe Study of CEO Leadership Behavior and Effectiveness in 24 Countries. : Sage Publications.

Hu, L. T., \& Bentler, P. M. (1999). Cutoff Criteria for Fit Indexes in Covariance Structure Analysis: Conventional Criteria Versus New Alternatives. Structural Equation Modeling: A Multidisciplinary Journal, 6(1), 155 .

Husted, K., Michailova, S., Minbaeva, D. B., \& Pedersen, T. (2012). Knowledge-Sharing Hostility and Governance Mechanisms: An Empirical Test. Journal of Knowledge Management, 16(5), 754-773.

Hwang, A., \& Francesco, A. (2010). The Influence of Individualism-Collectivism and Power Distance on Use of Feedback Channels and Consequences for Learning. Academy of Management Learning \& Education, 9(2), 243-257.

Imai, L., \& Gelfand, M. J. (2010). The Culturally Intelligent Negotiator: The Impact of Cultural Intelligence (CQ) on Negotiation Sequences and Outcomes. Organizational Behavior and Human Decision Processes, 112(2), 83-98.

Kachra, A., \& White, R. E. (2008). Know-How Transfer: The Role of Social, Economic/Competitive, and Firm Boundary Factors. Strategic Management Journal, 29(4), 425-445.

Karabenick, S. A., \& Knapp, J. R. (1988). Help Seeking and the Need for Academic Assistance. Journal of Educational Psychology, 80(3), 406-408.

Kim, Y. J., \& Van Dyne, L. (2012). Cultural Intelligence and International Leadership Potential: The Importance of Contact for Members of the Majority. Applied Psychology, 61(2), 272-294.

Kogut, B., \& Singh, H. (1988). The Effect of National Culture on the Choice of Entry Mode. Journal of International Business Studies, 19(3), 411-432. 
Kogut, B., \& Zander, U. (1992). Knowledge of the Firm, Combinative Capabilities, and the Replication of Technology. Organization Science, 3(3), 383-397.

Kogut, B., \& Zander, U. (1993). Knowledge of the firm and the evolutionary theory of the multinational corporation. Journal of International Business Studies, 24(4), 625-645.

Kotabe, M., Dunlap-Hinkler, D., Parente, R., \& Mishra, H. (2007). Determinants of Cross-National Knowledge Transfer and its Effect on Firm Innovation. Journal Of International Business Studies, 38(2), 259-282.

Kostova, T., \& Roth, K., (2002). Adoption of an Organizational Practice by Subsidiaries of Multinational Corporations: Institutional and Relational Effects. Academy of Management Journal, 45, 215-233.

Leary, M. R., \& Kowalski, R. M. (1990). Impression Management: A Literature Review and Two-Component Model. Psychological Bulletin, 107(1), 34-47.

Lee, F. (1997). When the Going Gets Tough, Do the Tough Ask for Help? Help Seeking and Power Motivation in Organizations. Organizational Behavior and Human Decision Processes, 72(3), 336-363.

Lee, S., Adair, W., \& Seo, S.-J. (2013). Cultural Perspective Taking in Cross-Cultural Negotiation. Group Decision and Negotiation, 22(3), 389-405.

Lindell, M. K., \& Whitney, D. J. (2001). Accounting for Common Method Variance in Cross-Sectional Research Designs. Journal of Applied Psychology, 86(1), 114-121.

Lorenz, M. P., Ramsey, J. R., \& Richey, R. G. (2018). Expatriates' International Opportunity Recognition and Innovativeness: The Role of Metacognitive and Cognitive Cultural Intelligence. Journal of World Business, 53(2), 222-236.

Mäkelä, K., Andersson, U., \& Seppälä, T. (2012). Interpersonal Similarity and Knowledge Sharing within Multinational Organizations. International Business Review, 21(3), 439-451.

Mäkelä, K., \& Brewster, C. (2009). Interunit Interaction Contexts, Interpersonal Social Capital, and the Differing Levels of Knowledge Sharing. Human Resource Management, 48(4), 591-613.

Makela, K., Kalla, H. K., \& Piekkari, R. (2007). Interpersonal Similarity as a Driver of Knowledge Sharing within Multinational Corporations. International Business Review, 16(1), 1-22.

Malhotra, N. K., Kim, S. S., \& Patil, A. (2006). Common Method Variance in IS Research: A Comparison of Alternative Approaches and a Reanalysis of Past Research. Management Science, 52(12), 1865-1883.

Michailova, S., \& Husted, K. (2003). Knowledge-Sharing Hostility in Russian Firms. California Management Review, 45, 59-77.

Michailova, S., \& Minbaeva, D.B. (2012). Organizational values and knowledge sharing in multinational corporations: The Danisco case. International Business Review, 21(1), 59-70.

Minbaeva, D.B., (2007). Knowledge Transfer in Multinational Corporations. Management International Review, 47, 567-593.

Minbaeva, D.B., (2013). Strategic HRM in Building Micro-Foundations of Organizational Knowledge-Based Performance. Human Resource Management Review, 23, 378-390.

Minbaeva, D.B., Pedersen, T., Björkman, I., Fey, C.F., \& Park, H.J., (2003). MNC Knowledge Transfer, Subsidiary Absorptive Capacity, and HRM. Journal of International Business Studies, 34, 586-599.

Mor, S., Morris, M., \& Joh, J. (2013). Identifying and Training Adaptive Cross-Cultural Management Skills: The Crucial Role of Cultural Metacognition. Academy of Management Learning and Education, 12(3), 453475.

Morris, S. S., Zhong, B., \& Makhija, M. (2015). Going the Distance: The Pros and Cons of Expanding Employees' Global Knowledge Reach. Journal of International Business Studies, 46(5), 552-573.

Motohashi, K. (2015). Global Business Strategy Multinational Corporations Venturing into Emerging Markets. Tokyo: Springer Japan.

Mudambi, R., \& Navarra, P. (2004). Is Knowledge Power? Knowledge Flows,Subsidiary Power and Rent-Seeking within Mncs. Journal of International Business Studies, 35(5), 385-406.

Mudambi, R., Piscitello, L., \& Rabbiosi, L. (2014). Reverse Knowledge Transfer in MNEs: Subsidiary Innovativeness and Entry Modes. Long Range Planning, 47(1-2), 49-63.

Najafi-Tavani, Z., Giroud, A., \& Sinkovics, R. R. (2012). Mediating Effects in Reverse Knowledge Transfer Processes. Management International Review, 52(3), 461-488.

Najafi-Tavani, Z., Zaefarian, G., Naudé, P., \& Giroud, A. (2015). Reverse Knowledge Transfer and Subsidiary Power. Industrial Marketing Management, 48, 103-110.

Nebus, J. (2006). Building Collegial Information Networks: A Theory of Advice Network Generatio. The Academy of Management Review, 31(3), 615-637.

Noorderhaven, N., \& Harzing, A.-W. (2009). Knowledge-Sharing and Social Interaction within MNEs. Journal of International Business Studies, 40(5), 719-741.

Ott, D. L., \& Michailova, S. (2018). Cultural Intelligence: A Review and New Research Avenues. International Journal of Management Reviews, 20(1), 99-119.

Park, J., Chae, H., \& Choi, J. N. (2017). The Need for Status as a Hidden Motive of Knowledge-Sharing Behavior: An Application of Costly Signaling Theory. Human Performance, 30(1), 21-37. 
Pfeffer, J., \& Fong, C. T. (2005). Building Organization Theory from First Principles: The Self-Enhancement Motive and Understanding Power and Influence. Organization Science, 16(4), 372-388.

Phene, A., \& Almeida, P. (2008). Innovation in Multinational Subsidiaries: The Role of Knowledge Assimilation and Subsidiary Capabilities. Journal of International Business Studies, 39(5), 901-919.

Podolny, J. M. (2001). Networks as the Pipes and Prisms of the Market. American Journal of Sociology, 107(1), $33-60$.

Reade, C. (2001). Dual Identification in Multinational Corporations: Local Managers and Their Psychological Attachment to the Subsidiary Versus the Global Organization. International Journal of Human Resource Management, 12(3), 405-424.

Reagans, R., \& McEvily, B. (2003). Network Structure and Knowledge Transfer: The Effects of Cohesion and Range. Administrative Science Quarterly, 48(2), 240-267.

Reiche, B.S., Harzing A.-W, \& \& Pudelko, M. (2015). Why and How Does Shared Language Affect Subsidiary Knowledge Inflows? A Social Identity Perspective. Journal of International Business Studies, 46(5), 528-551.

Reinholt, M., Pedersen, T., \& Foss, N. J. (2011). Why a Central Network Position Isn't Enough: The Role of Motivation and Ability for Knowledge Sharing in Employee Networks. Academy of Management Journal, 54(6), 1277-1297.

Richter, A. W., West, M. A., Van Dick, R., \& Dawson, J. F. (2006). Boundary Spanners' Identification, Intergroup Contact, and Effective Intergroup Relations. The Academy of Management Journal, 49(6), 1252-1269.

Rocha, V., van Praag, M., Folta, T. B., \& Carneiro, A. (2019). Endogeneity in Strategy-Performance Analysis: An Application to Initial Human Capital Strategy and New Venture Performance. Organizational Research Methods, 22(3), 740-764.

Rockstuhl, T., \& Van Dyne, L., 2018. A Bi-factor Theory of the Four-factor Model of Cultural Intelligence: Metaanalysis and Theoretical Extensions. Organizational Behaviour \& Human Decision Processes, 148, 124144.

Schlenker, B. R., \& Weigold, M. F. (1992). Interpersonal Processes Involving Impression Regulation and Management. Annual Review of Psychology, 43, 133-168.

Schlegelmilch, B.B., \& Chini, T.C. (2003). Knowledge Transfer Between Marketing Functions in Multinational Companies: A Conceptual Model. International Business Review, 12, 215-232.

Schotter, A. P. J., Mudambi, R., Doz, Y. L., \& Gaur, A. (2017). Boundary Spanning in Global Organizations. Journal of Management Studies, 54(4), 403-421.

Schrader, S. (1991). Informal Technology Transfer between Firms: Cooperation through Information Trading. Research Policy, 20(2), 153-170.

Sharma, R. R. (2019). Cultural Intelligence and Institutional Success: The Mediating Role of Relationship Quality. Journal of International Management, 25(3), 100665

Smale, A., Björkman, I., Ehrnrooth, M., John, S., Mäkelä, K., \& Sumelius, J. (2015). Dual Values-Based Organizational Identification in MNC Subsidiaries: A Multilevel Study. Journal of International Business Studies, 46(7), 761-783.

Smidts, A., Pruyn, A., \& van Riel, C. B. M. (2001). The Impact of Employee Communication and Perceived External Prestige on Organizational Identification. Academy of Management Journal, 44(5), 1051-1062.

Smith, P. K., Smallman, R., \& Rucker, D. D. (2016). Power and categorization: Power increases the number and abstractness of categories. Social Psychological and Personality Science, 7(3), 281-289.

Szulanski, G., (1996). Exploring Internal Stickiness: Impediments to the Transfer of Best Practice within the Firm. Strategic Management Journal, 17, 27-43.

Tajfel, H. (1978). Differentiation between Social Groups : Studies in the Social Psychology of Intergroup Relations. London: Published in cooperation with European Association of Experimental Social Psychology by Academic Press.

Tajfel, H., \& Turner, J. C. (1979). An Integrative Theory of Intergroup Conflict. In A. W. W. S. (Eds) (Ed.), The Social Psychology of Intergroup Relations, 33-47).

Terry, D. J., \& Hogg, M. A. (1996). Group Norms and the Attitude-Behavior Relationship: A Role for Group Identification. Personality and social psychology bulletin, 22(8), 776-793.

Thomas, D., Liao, Y., Aycan, Z., Cerdin, J.-L., Pekerti, A., Ravlin, E., . . . Van De Vijver, F. (2015). Cultural Intelligence: A Theory-Based, Short Form Measure. Journal of International Business Studies, 46(9), 1099-1118.

Tsai, W., (2002). Social Structure of "Coopetition" within a Multiunit Organization: Coordination, Competition, and Intraorganizational Knowledge Sharing. Organization Science, 13, 179-190.

Tseng, C.-H., (2015). Determinants of MNC's Knowledge Inflows to Subsidiaries: A Perspective on Internalization Advantages. Management International Review, 55, 119-150.

Turner, J. C. (1975). Social Comparison and Social Identity: Some Prospects for Intergroup Behaviour. European Journal of Social Psychology, 5(1), 1-34. 
Vlajčić, D., Caputo, A., Marzi, G., \& Dabić, M. (2019). Expatriates Managers' Cultural Intelligence as Promoter of Knowledge Transfer in Multinational Companies. Journal of Business Research, 94, 367-377.

Vora, D., \& Kostova, T. (2007). A Model of Dual Organizational Identification in the Context of the Multinational Enterprise. Journal of Organizational Behavior, 28(3), 327-350.

Whittle, A., Mueller, F., Gilchrist, A., \& Lenney, P. (2016). Sensemaking, Sense-Censoring and Strategic Inaction: The Discursive Enactment of Power and Politics in a Multinational Corporation. Organization Studies, 37(9), 1323-1351.

Wong, S.-S., Ho, V. T., \& Lee, C. H. (2008). A Power Perspective to Interunit Knowledge Transfer: Linking Knowledge Attributes to Unit Power and the Transfer of Knowledge. Journal of Management, 34(1), 127150.

Zhao, X., Lynch Jr, J.G., \& Chen, Q., (2010). Reconsidering Baron and Kenny: Myths and truths about mediation analysis. Journal of Consumer Research, 37, 197-206. 
Figure 1: Conceptual model

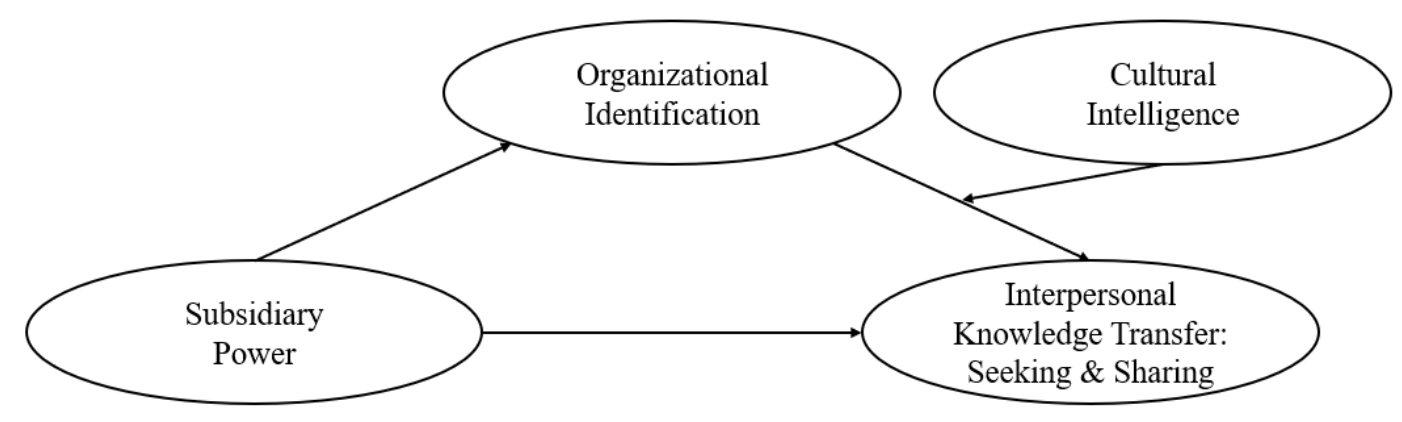

Figure 2: Conditional effects of subsidiary power on knowledge seeking at various values of cultural intelligence

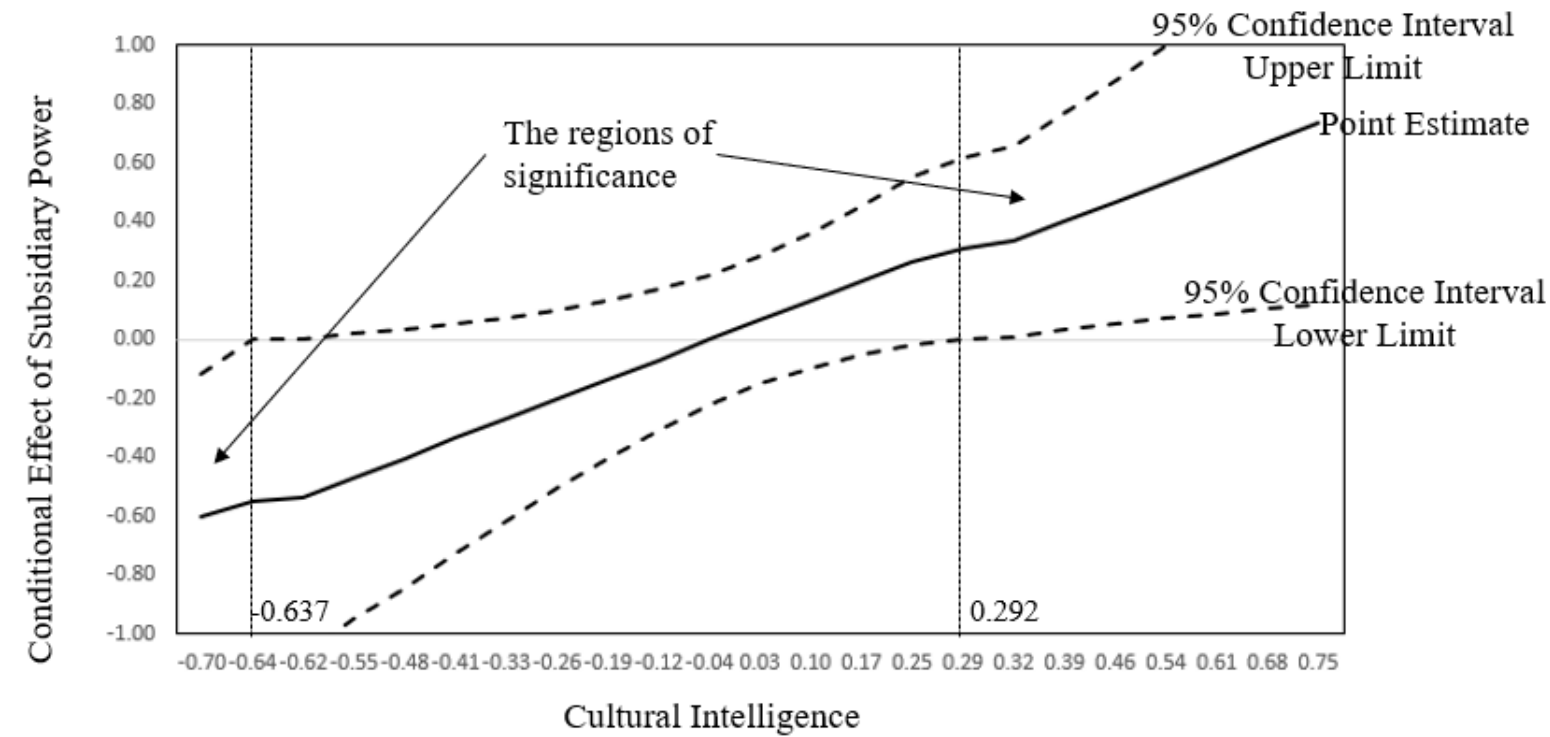


Table 1 Sample characteristics of respondents

\begin{tabular}{lll}
\hline R\&D characteristics $(\mathrm{N}=40)$ & Manufacturing & $92 \%$ \\
Industry & Services & $8 \%$ \\
Home country & USA & $40 \%$ \\
& Europe \& UK & $42 \%$ \\
& Asia-China, Japan, Korea & $18 \%$ \\
Respondent characteristics $(\mathrm{N}=333)$ & & \\
Gender & Male & $97 \%$ \\
& Female & $3 \%$ \\
Age & $20-29$ & $4 \%$ \\
& $30-39$ & $26 \%$ \\
& $40-49$ & $51 \%$ \\
& $50-59$ & $16 \%$ \\
Qualification & 60 and above & $3 \%$ \\
Tenure & Graduate & $44 \%$ \\
& Post-Graduate & $56 \%$ \\
& $\leq 5 y e a r s$ & $36 \%$ \\
\hline
\end{tabular}


Table 2: Second-order confirmatory factor analysis

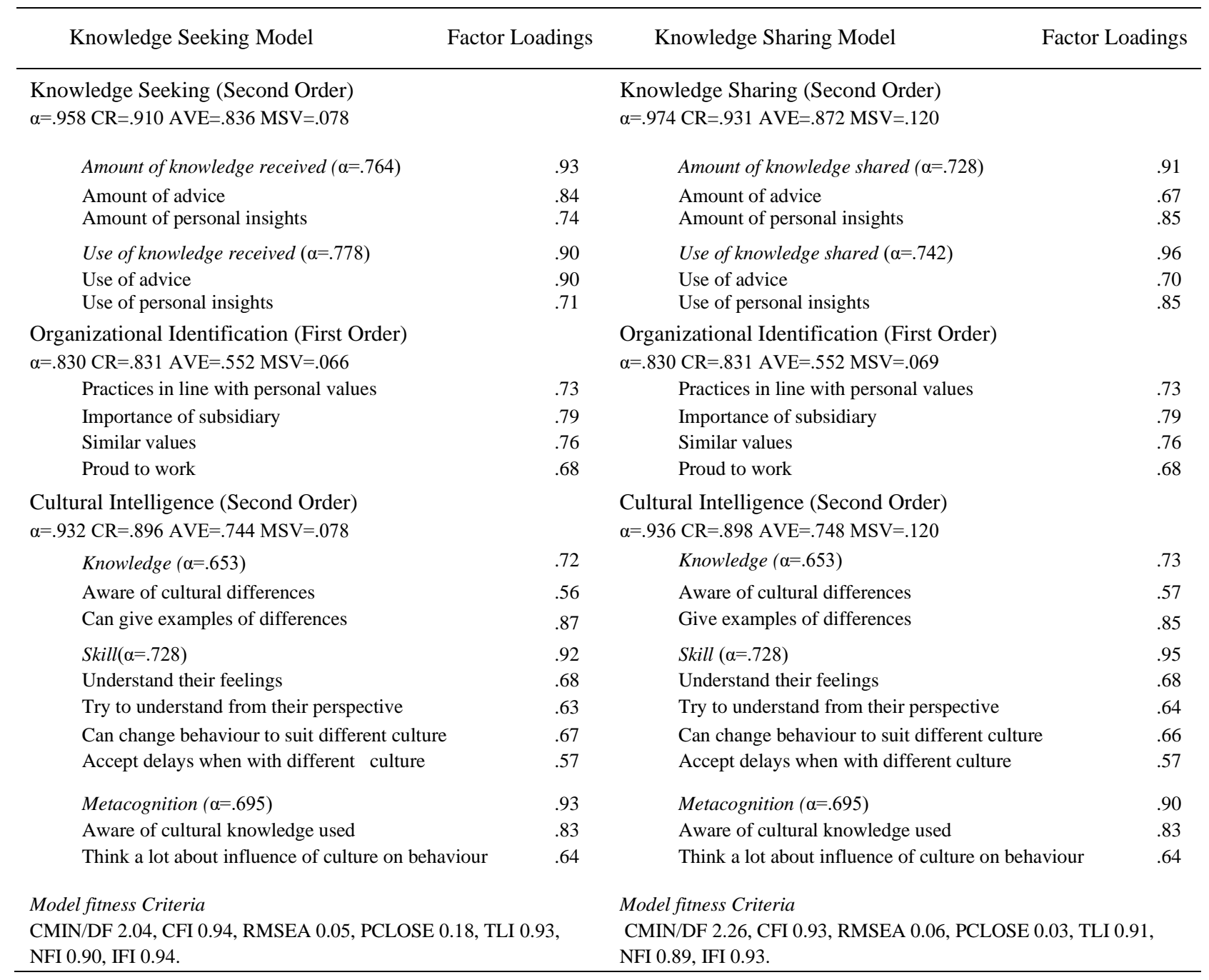

Notes: $\alpha=$ Cronbach's alpha, $C R=$ Composite reliability, $\mathrm{AVE}=$ Average variance extracted, $\mathrm{MSV}=$ Maximum Shared Variance, $\mathrm{CFI}=$ Comparative mean index, TLI = Tucker-Lewis Index, RMSEA = Root Mean Square of Approximation, PCLOSE $=$ Closeness of fit, NFI $=$ Normed Fit Index, IFI = Incremental Fit Index 
Table 3: Correlation table

\begin{tabular}{|c|c|c|c|c|c|c|c|c|c|c|c|c|c|c|}
\hline & Variables & Mean & SD & 1 & 2 & 3 & 4 & 5 & 6 & 7 & 8 & 9 & 10 & 11 \\
\hline 1 & $\begin{array}{l}\text { Knowledge Seek } \\
\text { (Share) }\end{array}$ & $\begin{array}{l}.000 \\
(.000)\end{array}$ & $\begin{array}{l}0.900 \\
(0.525)\end{array}$ & $\begin{array}{l}0.914 \\
(0.933)\end{array}$ & & & & & & & & & & \\
\hline 2 & $\begin{array}{l}\text { Subsidiary } \\
\text { Power }\end{array}$ & $\begin{array}{l}-0.771 \\
(-0.699) \\
\end{array}$ & $\begin{array}{l}0.881 \\
(0.903)\end{array}$ & $\begin{array}{l}0.087 \\
\left(0.179^{* *}\right)\end{array}$ & 1(1) & & & & & & & & & \\
\hline 3 & $\begin{array}{l}\text { Organizational } \\
\text { Identification }\end{array}$ & $\begin{array}{l}.000 \\
(.000)\end{array}$ & $\begin{array}{l}0.475 \\
(0.475) \\
\end{array}$ & $\begin{array}{l}0.156^{* *} \\
(0.112 *) \\
\end{array}$ & $\begin{array}{l}0.130 * \\
(127 *)\end{array}$ & $\begin{array}{l}0.742 \\
(.742)\end{array}$ & & & & & & & & \\
\hline 4 & \begin{tabular}{|l|} 
Cultural \\
Intelligence
\end{tabular} & $\begin{array}{l}.000 \\
(.000)\end{array}$ & $\begin{array}{l}0.261 \\
(0.269) \\
\end{array}$ & \begin{tabular}{|l}
$0.331 * *$ \\
$\left(0.410^{* *}\right)$ \\
\end{tabular} & $\begin{array}{l}0.087 \\
(0.141 *)\end{array}$ & $\begin{array}{l}0.303^{* *} \\
\left(0.307^{* *}\right) \\
\end{array}$ & $\begin{array}{l}\mathbf{0 . 8 6 2} \\
(\mathbf{0 . 8 6 4 )}\end{array}$ & & & & & & & \\
\hline 5 & Age & $\begin{array}{l}0.537 \\
(.577) \\
\end{array}$ & $\begin{array}{l}0.499 \\
(0.494)\end{array}$ & $\begin{array}{l}-0.093 \\
(0.001)\end{array}$ & $\begin{array}{l}0.043 \\
(0.062)\end{array}$ & $\begin{array}{l}0.032 \\
(0.084)\end{array}$ & $\begin{array}{l}0.043 \\
(0.090)\end{array}$ & $1(1)$ & & & & & & \\
\hline 6 & Tenure & $\begin{array}{l}7.853 \\
(7.843) \\
\end{array}$ & $\begin{array}{l}4.463 \\
(4.466) \\
\end{array}$ & $\begin{array}{l}0.134^{*} \\
(0.063)\end{array}$ & $\begin{array}{l}0.005 \\
(-0.010)\end{array}$ & $\begin{array}{l}0.266^{* * *} \\
(0.264 * *)\end{array}$ & $\begin{array}{l}-0.013 \\
(-0.013) \\
\end{array}$ & $\begin{array}{l}0.038 \\
(0.026) \\
\end{array}$ & $1(1)$ & & & & & \\
\hline 7 & Education & $\begin{array}{l}0.557 \\
(.557) \\
\end{array}$ & \begin{tabular}{|l|}
0.497 \\
$(0.497)$
\end{tabular} & $\begin{array}{l}-0.065 \\
(-0.025) \\
\end{array}$ & $\begin{array}{l}-0.045 \\
(-0.045)\end{array}$ & $\begin{array}{l}0.151^{* *} \\
\left(0.152^{* *}\right)\end{array}$ & $\begin{array}{l}0.023 \\
(0.025)\end{array}$ & $\begin{array}{l}0.086 \\
(0.023)\end{array}$ & $\begin{array}{l}0.105 \\
(0.103)\end{array}$ & 1(1) & & & & \\
\hline 8 & \begin{tabular}{|l|} 
Task \\
Dependency
\end{tabular} & $\begin{array}{l}3.03 \\
(2.91)\end{array}$ & $\begin{array}{l}0.766 \\
(1.083) \\
\end{array}$ & $\begin{array}{l}0.058 \\
(-0.163 * *)\end{array}$ & $\begin{array}{l}-0.054 \\
(0.047) \\
\end{array}$ & $\begin{array}{l}0.055 \\
(-0.062) \\
\end{array}$ & $\begin{array}{l}-0.082 \\
(0.101)\end{array}$ & $\begin{array}{l}-0.039 \\
(0.049) \\
\end{array}$ & $\begin{array}{l}0.137^{*} \\
(-0.010)\end{array}$ & $\begin{array}{l}0.003 \\
(.017) \\
\end{array}$ & $1(1)$ & & & \\
\hline 9 & $\begin{array}{l}\text { Subsidiary } \\
\text { Size }\end{array}$ & $\begin{array}{l}4.214 \\
(3.645)\end{array}$ & \begin{tabular}{|l|}
0.653 \\
$(0.495)$
\end{tabular} & $\begin{array}{l}0.064 \\
(0.015)\end{array}$ & $\begin{array}{l}-0.066 \\
(0.015)\end{array}$ & $\begin{array}{l}0.014 \\
(-0.066)\end{array}$ & $\begin{array}{l}0.167 * * \\
(0.092)\end{array}$ & $\begin{array}{l}-0.067 \\
(0.059)\end{array}$ & $\begin{array}{l}0.005 \\
(0.055)\end{array}$ & $\begin{array}{l}0.127^{*} \\
(0.060)\end{array}$ & $\begin{array}{l}0.006 \\
(0.041)\end{array}$ & $1(1)$ & & \\
\hline 10 & $\begin{array}{l}\text { Geographic } \\
\text { Distance }\end{array}$ & $\begin{array}{l}3.725 \\
(3.716)\end{array}$ & $\begin{array}{l}0.162 \\
(0.168)\end{array}$ & $\begin{array}{l}-0.011 \\
(-0.025)\end{array}$ & $\begin{array}{l}0.068 \\
(-0.025)\end{array}$ & $\begin{array}{l}0.035 \\
(0.039)\end{array}$ & $\begin{array}{l}-0.029 \\
(-0.043)\end{array}$ & $\begin{array}{l}0.088 \\
(0.058)\end{array}$ & $\begin{array}{l}0.144^{*} \\
(0.183 * *)\end{array}$ & $\begin{array}{l}-0.015 \\
(-0.003)\end{array}$ & $\begin{array}{l}-0.023 \\
(0.023)\end{array}$ & $\begin{array}{l}-0.062 \\
\left(-0.270^{* *}\right)\end{array}$ & $1(1)$ & \\
\hline 11 & $\begin{array}{l}\text { Cultural } \\
\text { Distance }\end{array}$ & $\begin{array}{l}1.781 \\
(1.710) \\
\end{array}$ & $\begin{array}{l}0.550 \\
(0.642) \\
\end{array}$ & $\begin{array}{l}0.020 \\
(-0.088) \\
\end{array}$ & $\begin{array}{l}-0.026 \\
(-0.088) \\
\end{array}$ & $\begin{array}{l}0.009 \\
(0.055)\end{array}$ & $\begin{array}{l}0.048 \\
(-0.041) \\
\end{array}$ & $\begin{array}{l}0.019 \\
(0.007)\end{array}$ & $\begin{array}{l}0.016 \\
(0.070)\end{array}$ & \begin{tabular}{|l}
0.108 \\
$(0.108)$ \\
\end{tabular} & $\begin{array}{l}0.179 * * \\
(-0.036) \\
\end{array}$ & $\begin{array}{l}-0.087 \\
(0.077) \\
\end{array}$ & $\begin{array}{l}-0.133 * \\
(-0.029) \\
\end{array}$ & $1(1)$ \\
\hline
\end{tabular}


Table 4: Mediation results (Process model 4)

\begin{tabular}{|c|c|c|c|c|}
\hline & \multicolumn{2}{|c|}{ Knowledge Seeking Model } & \multicolumn{2}{|c|}{ Knowledge Sharing Model } \\
\hline Variable & $\begin{array}{c}\text { Organizational } \\
\text { Identification } \\
\left(\mathrm{F} 4.521 * * *, \mathrm{R}^{2} 0.10\right)\end{array}$ & $\begin{array}{c}\text { Knowledge } \\
\text { Seeking } \\
\left.\text { (F } 2.169^{*}, \mathrm{R}^{2} 0.06\right)\end{array}$ & $\begin{array}{c}\text { Organizational } \\
\text { Identification } \\
\left.\text { (F 3.648***, } \mathrm{R}^{2} 0.09\right)\end{array}$ & 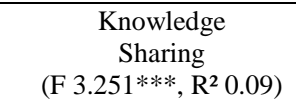 \\
\hline Constant & $0.018(-1.334,1.371)$ & $-0.871(-3.507,1.763)$ & $0.430(-1.013,1.875)$ & $0.672(-0.920,2.265)$ \\
\hline Subsidiary Power & $0.082 * *(0.024,0.140)$ & $0.059(-0.055,0.174)$ & $0.061 *(0.001,0.121)$ & $0.102 * *(0.036,0.169)$ \\
\hline Organizational Identification & & $0.277 *(0.056,0.498)$ & & $0.071(-0.057,0.200)$ \\
\hline Age & $0.007(-0.096,0.111)$ & $-0.180^{\dagger}(-0.383,0.021)$ & $0.068(-0.038,0.174)$ & $0.009(-0.108,0.127)$ \\
\hline Tenure & $0.025 * * *(0.013,0.037)$ & $0.018(-0.004,0.042)$ & $0.024 * * *(0.012,0.036)$ & $0.008(-0.004,0.022)$ \\
\hline Task Dependency & $0.023(-0.044,0.091)$ & $0.022(-0.110,0.155)$ & $-0.020(-0.068,0.026)$ & $-0.081 * *(-0.133,-0.028)$ \\
\hline Education & $0.142 * *(0.036,0.247)$ & $-0.172(-0.380,0.035)$ & $0.109 *(0.003,0.216)$ & $-0.033(-0.152,0.084)$ \\
\hline Subsidiary size & $-0.011(-0.091,0.069)$ & $0.091(-0.064,0.248)$ & $-0.069(-0.188,0.048)$ & $0.092(-0.038,0.223)$ \\
\hline Geographic distance & $-0.055(-0.386,0.275)$ & $0.097(-0.547,0.741)$ & $-0.086(-0.426,0.253)$ & $-0.160(-0.534,0.214)$ \\
\hline Cultural distance & $-0.028(-0.126,0.069)$ & $0.084(-0.106,0.275)$ & $-0.013(-0.102,0.076)$ & $-0.080(-.0178,0.018)$ \\
\hline Index of mediation & \multicolumn{2}{|c|}{$0.022(0.002,0.052)$} & \multicolumn{2}{|c|}{$0.007(-0.004,0.028)$} \\
\hline
\end{tabular}

Table 5: Moderated mediation results (Process model 14)

\begin{tabular}{|c|c|c|c|c|}
\hline \multirow[b]{2}{*}{ Variable } & \multicolumn{2}{|c|}{ Knowledge Seeking Model } & \multicolumn{2}{|c|}{ Knowledge Sharing Model } \\
\hline & $\begin{array}{c}\text { Organizational } \\
\text { Identification } \\
\left(\mathrm{F} 4.521^{* * *}, \mathrm{R}^{2} 0.10\right)\end{array}$ & $\begin{array}{c}\text { Knowledge } \\
\text { Seeking } \\
\left(\mathrm{F} 6.338^{* * *}, \mathrm{R}^{2} 0.19\right)\end{array}$ & $\begin{array}{c}\text { Organizational } \\
\text { Identification } \\
\left.\text { (F 3.648***, } \mathrm{R}^{2} 0.09\right)\end{array}$ & $\begin{array}{c}\text { Knowledge } \\
\text { Sharing } \\
\left(\mathrm{F} 8.596^{* * *}, \mathrm{R}^{2} 0.25\right)\end{array}$ \\
\hline Constant & $0.018(-1.334,1.371)$ & $-0.983(-3.444,1.478)$ & $0.430(-1.013,1.875)$ & $0.728(-0.726,2.183)$ \\
\hline Subsidiary Power & $0.082 * *(0.024,0.140)$ & $0.036(-0.070,0.143)$ & $0.061 *(0.001,0.121)$ & $0.073 *(0.012,0.134)$ \\
\hline Organizational Identification (OI) & & $0.038(-0.179,0.255)$ & & $-0.083(-0.207,0.040)$ \\
\hline Cultural Intelligence (CQ) & & $1.221 * * *(0.839,1.604)$ & & $0.795 * * *(0.585,1.004)$ \\
\hline OI x CQ & & $0.924 *(0.144,1.704)$ & & $0.217(-0.214,0.648)$ \\
\hline Age & $0.007(-0.096,0.111)$ & $-0.219 *(-0.408,-0.030)$ & $0.068(-0.038,0.174)$ & $-0.020(-0.128,0.088)$ \\
\hline Tenure & $0.025 * * *(0.013,0.037)$ & $0.029 *(0.006,0.051)$ & $0.024 * * *(0.012,0.036)$ & $0.015 *(0.002,0.027)$ \\
\hline Task Dependency & $0.023(-0.044,0.091)$ & $0.077(-0.047,0.202)$ & $-0.020(-0.068,0.026)$ & $-0.104 * * *(-0.152,-0.056)$ \\
\hline Education & $.142 * *(0.036,0.247)$ & $-0.152(-0.347,0.041)$ & $0.109 *(0.003,0.216)$ & $-0.025(-0.133,0.082)$ \\
\hline Subsidiary size & $-0.011(-0.091,0.069)$ & $-0.022(-0.171,0.127)$ & $-0.069(-0.188,0.048)$ & $0.018(-0.102,0.139)$ \\
\hline Geographic Distance & $-0.055(-0.386,0.275)$ & $0.195(-0.406,0.797)$ & $-0.086(-0.426,0.253)$ & $-0.115(-0.457,0.226)$ \\
\hline Cultural Distance & $-0.028(-0.126,0.069)$ & $0.044(-0.134,0.222)$ & $-0.013(-0.102,0.076)$ & $-0.055(-0.146,0.034)$ \\
\hline Index of moderated mediation & \multicolumn{2}{|c|}{$0.076(0.003,0.178)$} & \multicolumn{2}{|c|}{$0.013(-0.022,0.061)$} \\
\hline
\end{tabular}




\title{
Appendix 1: Questionnaire items for the conceptual model measurements
}

\author{
Constructs, Sources and Items
}

Subsidiary Power (Ambos et al., 2010; Nazafi-Tavani et al, 2015): Please rank your subsidiary and the contact's subsidiary regarding how much power they have within the multinational. Power is the subsidiary's ability to influence HQ's decisions and its ability to take decisions autonomously with less control from the HQ. ( $1=$ Very little, $2=$ little, $3=$ Neither little nor much, $4=$ Much, $5=$ Very much)

Ability of the subsidiaries (your subsidiary \& the contact's subsidiary) to influence HQ's decisions

$$
\text { Your subsidiary Contact's subsidiary }
$$

Ability of the subsidiaries (your subsidiary \& the contact's subsidiary) to take decisions autonomously with less control from the HQ
Your subsidiary
Contact's subsidiary

Knowledge Seeking (Hansen, 2002; Kogut and Zanger, 1992; Mäkelä and Brewster, 2009): Please keep the identified contact in mind and rate the following statements about the amount of knowledge/information you have received from this contact

During the last 12 months I have received from the identified contact $(1=$ Very little, $2=$ Little, $3=$ Neither little nor much, $4=$ Much, $5=$ Very much)
Advice to deal with work related problem
Personal insights about work

Please rate the $\underline{\text { usefulness }}$ of knowledge / information you have received from this contact. ( $1=$ Not at all useful, $2=$ Slightly useful, 3 = Useful, 4=Very useful, 5=Extremely useful)

Advice to deal with work related problem Personal insights about work

Organizational Identification (Reade, 2001; Smale et al., 2015): Please rate the followings for your subsidiary (1=Strongly disagree, $2=$ Disagree, $3=$ Neither agree nor disagree, $4=$ Agree, $5=$ Strongly agree)

The practices of this local unit/subsidiary are in line with my personal values

What this local unit/subsidiary stands for is important to me

My values and the values of the local unit/subsidiary that I work for are the same

I am proud to tell others that I am an employee of this company

Cultural Intelligence (Thomas et al., 2015): Please indicate to what extent each of the following statements truly describes you. These statements are about your experience when interacting with people from other cultures. $(1=$ Not at all, $2=\mathrm{A}$ little, $3=$ Somewhat, 4 = A lot, $5=$ Extremely well)

Cultural knowledge

I know the ways in which cultures around the world are different.

I can give examples of cultural differences from my personal experience, reading, and so on.

Cultural skills

I have the ability to accurately understand the feelings of people from other cultures.

I try to understand people from another culture by imagining how something looks from their perspective.

I can change my behaviour to suit different cultural situations and people.

I accept delays without becoming upset when in different cultural situations and with culturally different people.

Cultural metacognition

I am aware of the cultural knowledge I use when interacting with someone from another culture.

I think a lot about the influence that culture has on my behaviour and that of others who are culturally different.

Marker Variable (Chan, 2009; Lertwannawit \& Mandhachitara; Lindell and Whitney, 2001, Malhotra et al, 2006): Please rate your fashion consciousness. How important is it for you to dress fashionably? (1=Strongly disagree, $2=$ Disagree, $3=$ Neither agree nor disagree, $4=$ Agree, $5=$ Strongly agree)

An important part of my life and activities is dressing smartly

A person should try to dress in style

Task Dependency (Haas \& Cummings, 2015): Was it possible for you to accomplish task for which you sought/gave advice, without information or materials from/to this person. 5 -point scale: $1=$ not at all possible, $2=$ less possible, $3=$ somewhat possible, 4 = much possible, 5 = very much possible.

Note: Questions on subsidiary power, knowledge transfer and task precedency were asked twice: once for knowledge seeking and then for knowledge sharing. The reason for asking twice for knowledge sharing and seeking is that the 'contact subsidiary' from which knowledge is sought may not be the same contact subsidiary with whom knowledge is shared. 